\title{
Are transboundary fisheries management arrangements in the Northwest Atlantic and North Pacific seaworthy in a changing ocean?
}

\author{
Olga Koubrak ${ }^{1}$ and David L. VanderZwaag ${ }^{1}$
}

\begin{abstract}
Climate change is affecting physical and biological components and processes of marine ecosystems in many ways. Resulting changes in abundance and distribution of commercially valuable species are anticipated to create or exacerbate challenges for fisheries management across national boundaries by raising questions around catch allocation, membership in the management organizations, and forms of cooperation between the organizations. In this paper we assess eight transboundary fisheries arrangements in the Northwest Atlantic and North Pacific on their preparedness to respond to climate-change driven changes. For each arrangement a three-part analysis is provided. A general introduction to fisheries management responsibilities, including species and geographic scope, is first followed by a review of how climate-related science is being supported and a discussion of how climate change is being addressed directly or indirectly in management. The review shows that none of the examined treaties and founding documents mention climate change or direct parties to include climate change in their research programs and management measures. Nevertheless, climate change is on the radar screen of all eight arrangements although adopting management approaches that do not rely on single stock assessments remains politically difficult. The seaworthiness of the eight arrangements to address climate change varies considerably. Three arrangements were categorized as the most seaworthy for investing significant resources in ecosystem-based management and climate science. Three were assessed to be moderately seaworthy for recognizing precautionary and ecosystem approaches in their treaties, or for taking steps toward this objective, as well as supporting climate science. However, they are relying on single-stock management and, at times, struggle with making decisions based on scientific evidence. Two arrangements appear to be least seaworthy because they are largely ignoring climate change and the need for an ecosystem approach in their management or have inadequate legal tools to address these needs effectively.
\end{abstract}

Key Words: climate change; ecosystem approach; fisheries management; international law; ocean acidity; precautionary approach

\section{INTRODUCTION}

Climate change, with its many impacts on marine ecosystems through shifts in temperature (Laffoley and Baxter 2016), acidity (Secretariat of the Convention on Biological Diversity 2014), salinity, oxygen levels, and ocean circulation (Seggel and DeYoung 2016), promises to complicate fisheries management at all levels (Pinsky et al. 2018), but especially the management of fish populations that move across national boundaries. Geographical shifts in fish distributions may raise new harvesting allocation questions at the bilateral and regional levels and may even raise the need for new management arrangements, for example, greater cooperation among regional fisheries management organizations (RFMOs) that confront a new shared resource (Rayfuse 2019). How to apply precautionary and ecosystem approaches under existing transboundary fisheries agreements and arrangements to account for changing ocean conditions promises to be challenging in light of socioeconomic pressures (Russell and VanderZwaag 2010a) and a traditional tendency to treat fish populations as geographically static (Pinsky et al. 2018).

Although the need to anticipate and adapt to shifts in fisheries managed species has been well documented (e.g., Grafton 2010, Heenan et al. 2015, DeCaro et al. 2017), reviews of how existing transboundary fisheries organizations and arrangements are structured to respond to resource fluctuations caused by climate change and ocean acidity have been limited. For example, a 2017 paper, reviewing the academic literature relating to fisheries management and climate-driven risk, highlighted how decisionmaking approaches (majority vote versus consensus-based) within RFMOs may limit adaptiveness and emphasized the need for a greater research focus on institutional analysis on how scientific recommendations inform policy and practice (Pentz and Klenk 2017). A 2018 study, evaluating the framework of 12 RFMOs to effectively manage resources during climate change, excluded bilateral arrangements and was largely a "paper exercise" of scoring RFMOs in light of 28 criteria without detailed analysis of the actual scientific and political practices of the RFMOs (Pentz et al. 2018). Various papers have critiqued the performance of the five tuna RFMOs but without a focus on how climate change is being addressed (Juan-Jordá et al. 2018a, Pons et al. 2018). A recent chapter by Rosemary Rayfuse provides a more detailed analysis of how the five tuna RFMOs and some nontuna RFMOs are addressing climate change but with still quite limited institutional analysis and a choice to omit evaluation of any bilateral arrangements and the two international anadromous fisheries organizations (Rayfuse 2019).

In this article we aim to add to the literature on transboundary fisheries management in an era of climate change. We provide a detailed look at how climate change is being addressed in the major international fisheries management organizations and arrangements involving Canada off its North Atlantic and North Pacific coasts. For the Northwest Atlantic, these include the North Atlantic Salmon Conservation Organization (NASCO), the Northwest Atlantic Fisheries Organization (NAFO), the International Commission for the Conservation of Atlantic Tunas (ICCAT), and Canada-United States cooperative management of Georges Bank groundfish. For the Pacific, two RFMOs are addressed, the North Pacific Fisheries Commission (NPFC) and the Western and Central Pacific Fisheries Commission (WCPFC), along with two bilateral fisheries 
management organizations, the International Pacific Halibut Commission (IPHC), and the Pacific Salmon Commission (PSC). We use the term "transboundary" in a broad sense to include shared, straddling, and highly migratory fish stocks that cross national boundaries (Russell and VanderZwaag 2010b). This article attempts to be accurate in covering transboundary fisheries governance developments as of 1 June, 2020, the date of last article revisions.

We use the image of seaworthiness, a maritime term referring to preparedness of a ship to make a safe voyage, to assess the capabilities of regional and bilateral fisheries management arrangements to respond to climate change impacts and projections. Although numerous factors must be in place to ensure effective transboundary fisheries management, for example, robust monitoring and enforcement measures (Ásgeirsdóttir 2019, van der Marel 2019) and full participation of fishing parties (Molenaar 2019), we focus on factors especially important to address shifting species and ecosystems in a changing ocean. Those factors include: support for climate change and ecosystem science (Rayfuse 2019); development of a regional strategy or program for climate change adaptation (Engler 2020); adoption and implementation of precautionary and ecosystem approaches (Russell and VanderZwaag 2010a); agreement on principles for access and allocations and weighing of distribution shifts (Gullestad et al. 2020); consideration of climate change in decision making; and adoption of marine protected areas (MPAs) and other area-based measures (Dunn et al. 2019, Rayfuse 2019, Engler 2020). This is not a closed list and the overarching question is how climate change is being considered directly or indirectly in transboundary fisheries management practice.

\section{NORTHWEST ATLANTIC}

North Atlantic Salmon Conservation Organization

Established in 1984 pursuant to the Convention for the Conservation of Salmon in the North Atlantic Ocean (NASCO 2013), NASCO has a broad geographical mandate to promote international cooperation in conservation, restoration, enhancement, and rational management of salmon stocks in the North Atlantic (VanderZwaag and Pudden 2010). Under Article 1 of the Convention, NASCO's mandate extends to salmon stocks that migrate beyond areas of fisheries jurisdiction of coastal states of the Atlantic Ocean north of $36^{\circ} \mathrm{N}$ latitude throughout their migratory range. Salmon distribution in the Northeast Atlantic extends from northern Portugal to northern Russia and Iceland and the species ranges from northeastern United States (Connecticut) to northern Canada in the Northwest Atlantic with over 2000 rivers supporting salmon populations in the North Atlantic (ICES [date unknown]). NASCO has six parties: Canada, Denmark in respect of the Faroe Islands and Greenland, European Union, Norway, Russian Federation, and United States (NASCO [date unknown] a).

The regulatory powers of NASCO are very limited. The Convention itself substantially restricts the need for regulatory measures by prohibiting fishing of salmon on the high seas and beyond the 12 nautical mile territorial seas of coastal states with two exceptions. Fishing is allowed off West Greenland up to 40 nautical miles from the territorial sea baselines and within the area of fisheries jurisdiction of the Faroe Islands. Article 4(2) of the Convention gives NASCO's Council authority to make recommendations to parties on matters concerning salmon stocks, but the Council is not allowed to make recommendations covering the management of salmon harvests within the area of fisheries jurisdiction of a party. The regulatory powers of NASCO's three commissions, the North American Commission, the West Greenland Commission, and the Northeast Atlantic Commission, are limited to proposing regulatory measures for salmon fisheries under the jurisdiction of a particular member where the salmon being harvested originates from rivers located in another party's jurisdiction. Unanimous agreement among voting members of commissions is required to set regulatory measures. Only fisheries at West Greenland (NASCO [date unknown $] b$ ) and the Faroe Islands are presently subject to regulatory measures (NASCO [date unknown]c).

The International Council for the Exploration of the Sea (ICES), through its Working Group on North Atlantic Salmon (WGNAS), has been the main vehicle for obtaining yearly scientific advice on the status of salmon populations and fisheries, but climate change has only received general attention without any specific fisheries management advice. Beginning in 2011, NASCO began to ask ICES to report on new or emerging threats to, or opportunities for, salmon conservation and management including information on the potential implications of climate change for salmon management (NASCO 2011). Reports have focused on an array of threats including diseases, parasites, and predators, and have described various climate change effects, such as changing river flows and warmer water temperatures (ICES 2019). In 2016, NASCO did specifically ask ICES for a description of the potential future impacts of climate change on salmon stock dynamics (NASCO 2016a), but ICES in a subsequent May 2017 report explicitly noted that its discussions of potential climate change impacts were limited to impacts on salmon populations rather than to Atlantic salmon fisheries (ICES 2017). The report highlighted the many changes associated with climate change including water temperatures, freshening of surface ocean layers, increasing acidification and reduction of oxygen levels, and the continuing uncertainty over how Atlantic salmon populations will respond to novel conditions. The report described how climate change impacts may be both positive, for example, through increased growth and production in northern areas, but also negative, for example, through contraction of the southern part of the range and expansion of non-native species such as the smallmouth bass (Micropterus dolomieu), which is a salmon predator (ICES 2017).

A main challenge for NASCO has been to explain why marine survival has declined so markedly for salmon with many populations having disappeared or being endangered (Thorstad et al. 2011). For example, the United States has listed all of its North Atlantic salmon populations as endangered under the Endangered Species Act. Canada has listed inner Bay of Fundy salmon as endangered under the Species at Risk Act. Both countries have closed all their commercial fisheries (VanderZwaag et al. 2011). In 2017, only 1041 salmon were reported as returning to U.S. waters (U.S. Atlantic Salmon Assessment Committee 2018). Only 0-10 salmon return each year to most rivers in Canada's inner Bay of Fundy (Fisheries and Oceans Canada 2018). 
NASCO has attempted to promote scientific cooperation into the cause of maritime mortality, including the possible roles of climate change, through the International Atlantic Salmon Research Board (IASRB), which was established in 2001 (NASCO [date unknown]d). The Board initiated the Salmon at Sea (SALSEA) research program in 2004, which is dedicated to studying factors affecting migration and distribution of salmon at sea, and annual inventories of research projects have been provided (IASRB 2017). The latest phase of SALSEA, called SALSEA-Track, aims to advance the use of telemetry technology to precisely track salmon along their migration routes, to quantify mortality at different points and to identify the factors causing the mortality (NASCO 2016b).

NASCO has also partnered with the North Pacific Anadromous Fish Commission (NPAFC) in the International Year of the Salmon (IYS) initiative trying to foster greater understanding of the many uncertainties and challenges surrounding wild salmon conservation, including those of climate change. Titled "Salmon and People in a Changing World," the IYS had a focal year of 2019, but activities are expected to continue into 2022 (NASCO [date unknown]e). In May 2019, NPAFC hosted a Workshop on Salmon Ocean Ecology in a Changing Climate (NPAFC 2019). In June 2019, NASCO helped convene a symposium in Tromsø, Norway, in conjunction with NASCO's annual meeting, on the theme "Managing the Atlantic Salmon in a Rapidly Changing Environment - Management Challenges and Possible Responses." The report of the symposium reviews the impact of climate change on Atlantic salmon and recommends that NASCO should identify strategic activities to deal with climate change and its cascading effects on salmon and salmon habitat, possibly by updating its 2005 Strategic Approach for NASCO’s "Next Steps" (NASCO 2019a).

NASCO may be viewed as seaworthy on some fronts relating to managing the impact of climate change. For example, parties have agreed on the need for a precautionary approach to fisheries management (NASCO 1998, 1999) and habitat protection and restoration (NASCO 2001, 2010). Since 2001, no fishing quota has been issued for salmon fisheries off the Faroe Islands (NASCO [date unknown]c).

However, NASCO's seaworthiness remains questionable in other respects. NASCO's role is largely consultative and recommendatory with salmon fisheries management largely controlled by parties at the national level. Adaptive management of other stressors to wild salmon, such as habitat degradation and destruction, aquaculture operations and pollution, remain under the exclusive jurisdiction of the parties subject to national reporting on implementation of the NASCO agreements and guidelines (e.g., NASCO 2019b, c). A 2012 external performance review of NASCO highlighted the need to consider modernizing the NASCO Convention on various fronts, including to expressly embrace sustainability principles such as precautionary and ecosystem approaches, and to provide a clear legal basis for harmonizing and implementing national laws and policies (NASCO 2012), but parties have not proceeded to open the Convention to renegotiation. Fishers in St. Pierre and Miquelon, an overseas territory of France, continue to harvest salmon of North American origin without regulation by NASCO, and France has continually balked at becoming a NASCO party (NASCO 2018).
A particularly challenging "rough sea" for NASCO has been the regulation of the fishery at West Greenland, even without the complications of climate change. A major challenge has been to balance the need for conservation with the livelihoods of thousands of Greenlanders who rely on salmon for subsistence and cultural identity (NASCO 2014a, $b$ ). ICES has consistently recommended against authorizing a fishery off West Greenland because harvested salmon are a mixed stock with about $83 \%$ determined to be of North American origin and 17\% of European origin (ICES 2019) and because of the difficulty of setting appropriate catch limits where some of the contributing populations are in weak states and below their conservation limit. From 1998 to 2012, the management waters were relatively calm with the West Greenland Commission authorizing a commercial fishery but with an export prohibition. In all but two years the fishery was restricted to an internal-use fishery estimated at 20 tonnes (NASCO [date unknown]b). However, from 2012 to 2017, Greenland unilaterally set fishery quotas without the agreement of the West Greenland Commission. Licensed fishers were allowed to sell to local factories for the years 2012-2015, and in 2015 Greenland committed to limit the total annual catch to no more than 45 tonnes with any over harvest to be deducted from the following year's catch limit (West Greenland Commission 2015).

In 2018, the West Greenland Commission was again able to reach agreement on regulatory measures. Denmark in respect of Greenland agreed to restrict the total allowable catch (TAC) for all components of the fishery off West Greenland to 30 tonnes in 2018, 2019, and 2020 (West Greenland Commission 2018a). All fishers, even those fishing for personal consumption, will be required to have a fishing license. Only licensed full-time hunters and fishers would be authorized to sell Atlantic salmon only at open air markets in communities. All licensed fishers for Atlantic salmon would also be required to provide a full account of harvests with reporting on a daily basis (West Greenland Commission 2018a).

The management situation for the West Greenland salmon fishery might be described as an "uneasy balance." Climate change threats and impacts have yet to enter into the calculation of regulatory measures. An unreported harvest of Atlantic salmon is estimated to be about 10 tonnes per year (ICES 2019). As noted by the United States, the 30 tonne quota remains above the sustainable limit for the stock complex even though strong monitoring and control measures were agreed to (West Greenland Commission 2018b). Greenland has reported a 40.5 tonne catch of salmon at West Greenland in 2018, well above the agreed to quota (West Greenland Commission 2019), which further complicates the management picture. Greenland has committed to reduce the salmon harvest in 2019 to account for the 2018 overharvest and has set the 2019 quota at 19.5 tonnes (West Greenland Commission 2019).

\section{Northwest Atlantic Fisheries Organization}

Established in 1979 as a successor to the International Commission for Northwest Atlantic Fisheries, NAFO is responsible for managing fish stocks, other than salmon, tunas, billfish, cetaceans, and sedentary species, in the Regulatory Area of the Northwest Atlantic outside national 200 nautical mile zones. Eleven species with 19 stocks are presently subject to management (NAFO [date unknown] $a$ ). The three main regulated 
fisheries are for groundfish, shrimp, and pelagic redfish with 9 of the 19 stocks subject to a fishing moratorium as of 2019 (NAFO 2019a).

Although NAFO's poor record in fisheries management during the 1980s and 1990s is well documented (Russell 2010), NAFO has made some strides toward adopting and implementing precautionary and ecosystem approaches. NAFO adopted a precautionary approach framework to fisheries management in 2004 (NAFO 2004). In 2007 NAFO's Convention was modernized, with amendments coming into force 18 May 2017 (NAFO 2017a). Parties commit to apply an ecosystem approach to fisheries management; apply the precautionary approach in accordance with Article 6 of the 1995 UN Fish Stocks Agreement; take due account of the need to preserve marine biological diversity; and adopt measures based on the best scientific information available (NAFO 2017a).

NAFO has established various routes through which climate change impacts might be considered, but the integration of climate science into fisheries decision making appears to be minimal or nonexistent. NAFO's Scientific Council (SC) is tasked with providing scientific advice on the status of stocks and catch levels to NAFO's Commission, but other than on occasion noting in a general way changing ocean productivity and temperatures, the Scientific Council has not specifically based recommendations on environmental factors and projections (NAFO 2018a). The SC's Standing Committee on Fisheries Environment has published annual climate status summaries for the NAFO Convention Area and has provided annual highlights to the SC on climate and environmental conditions (NAFO 2018a). However, the scientific observations do not appear to have effected fisheries management (NAFO 2018b).

In 2008 the Scientific Council established a new Working Group on the Ecosystem Approach to Fisheries Management with the name changed in 2013 to the Working Group on Ecosystem Science and Assessment (WG-ESA). The Working Group has largely focused on identifying and delineating vulnerable marine ecosystems (VMEs), but has also worked to further develop ecosystem productivity modeling and multispecies models (NAFO 2015, 2019b).

In 2013, NAFO established a joint Fisheries CommissionScientific Council Working Group on Ecosystem Approach Framework to Fisheries Management (WG-EAFFM) to review progress toward implementing the ecosystem approach to fisheries (EAF) and to develop recommendations for addressing EAF (NAFO [date unknown] $b$ ). However, actual recommendations have been limited. For example, in 2017 the WG-EAFFM recommended modification of closed areas in the New England Seamounts (NAFO 2017b) and in 2018 urged parties to consider options other than scientific trawl surveys in closed areas and asked the SC to continue to refine its work on ecosystem models (NAFO 2018b).

NAFO has developed a Roadmap for the Development of an Ecosystem Approach to Fisheries, which was first endorsed in 2010 (NAFO 2010). The Roadmap is not a fixed plan, but sets three main directions for moving toward an ecosystem approach in setting catch limits (Koen-Alonso et al. 2019). A first tier is ecosystem state assessment, which aims to define ecosystem spatial units, to identify the productivity of the ecosystems and to provide advice on limits for total catches for each ecosystem unit (NAFO 2016a). A second tier is multispecies assessment, which seeks to describe species interactions and trends to understand the role of environmental drivers in ecosystem structure and dynamics and to eventually define multispecies reference points (Koen-Alonso et al. 2019). A third tier is stock assessment, which is advancing single species stock assessments but working toward setting catch levels based on ecosystem productivity and multispecies interactions (Koen-Alonso et al. 2019). Although the Scientific Council has adopted three pilot ecosystem production units (EPUs), Flemish Cap, the Grand Bank, and the Newfoundland Shelf (NAFO 2016a) and has made substantial progress in tiered modeling, management application of models has yet to occur. NAFO continues to rely on single species stock assessments (Soomai 2017).

The Roadmap lists as one of the priority work areas the understanding of the impacts of external factors such as climate change, oil and gas operations, and deep sea mining on ecosystem productivity (NAFO 2015). However, such work has faltered because of limited human resources in the Working Group on Ecosystem Science and Assessment (NAFO 2017b) and hesitancy by the Scientific Council to develop a work plan for assessing impacts other than fishing in the NAFO Regulatory Area. In 2016, the Scientific Council was asked to develop such a work plan, but the Council responded that development of such a work plan was beyond its capacity and purview (NAFO 2016b). The Council further noted that developing a work plan would require the joint effort from multidisciplinary experts drawn from various organizations and authorities (NAFO 2016b).

One of the major outputs of the Roadmap process is the eventual production of ecosystem summary sheets that will describe fishery production potentials and how environmental conditions are changing in the three pilot EPU areas. The summary sheets are expected to provide general guidance for setting total catch indices, and the summary sheet for the Grand Bank is viewed as a first example (NAFO 2019c). The Scientific Council is expected to present the summary sheet to the Commission at its 2020 Annual Meeting with a view to informing decision-making processes (NAFO 2019d).

Even without considering the possible complications associated with climate change, NAFO has struggled to implement the precautionary approach. NAFO has at times set some TACs without or above scientific advice. For example, in 2016 the Scientific Council stated that it was unable to advise on an appropriate TAC for redfish in Division 3O, yet the TAC for that stock was set at 20,000 tonnes for 2017, 2018, and 2019 (NAFO $2016 b$ ). In 2016, the SC also advised there should be no increase in catch of skates in Divisions 3LNO (approximately 4700 tonnes average between 2011 and 2015), yet the Commission approved a TAC of 7000 tonnes for 2017 and 2018 (NAFO 2016b). In 2017, $\mathrm{SC}$ recommended a $3 \mathrm{M}$ cod (Gadus morhua) quota of 8182 tonnes for 2018, yet a 11,145 tonne TAC was applied for 2018, reducing to 8182 tonnes in 2019 (NAFO 2017c). In 2019 the Scientific Council recommended TACs for redfish in Division $3 \mathrm{M}$ should not exceed 4320 tonnes in 2020 and 4624 tonnes in 2021 but the Commission agreed to TACs of 8590 tonnes in year 2020 and 8448 tonnes in year 2021 (NAFO 2019d). NAFO's 2018 
Performance Review noted that for 12 stocks, precautionary reference points were not available in one or both dimensions of biomass and fishery mortality and urged NAFO to give high priority and a clear time line for revising its precautionary approach framework, with a revision process instituted in 2016 but stalled (NAFO 2018c).

NAFO has made substantial progress in protecting VMEs from bottom trawling. Even though climate change has not been a factor in designation, reduction of fishing stresses may be viewed as an adaptive measure (Rayfuse 2019). NAFO has closed 20 areas to bottom fishing until 31 December 2020, including six seamount closures, and made other closures to protect high sponge, seapen, and coral concentrations (NAFO 2019a). For encounters with VME indicator species (coral, sponges or seapens) outside closed areas, NAFO has adopted a two nautical mile "move on" rule whereby fishing vessels have to cease fishing and move away from the end part of the tow in a direction least likely to result in further encounters (NAFO 2019a).

A 2018 performance review of NAFO highlighted the many difficulties of fully implementing the ecosystem approach and the still very limited consideration of climate change (NAFO 2018c). The review panel highlighted the lack of SC capacity to proactively work on emerging future advisory needs such as advice on addressing impacts of climate change. The panel recommended that NAFO, as a high priority, develop a plan and implement steps to match the scientific resources to the workload. The panel noted the slow development of NAFO's Roadmap towards an Ecosystem Approach to Fisheries Management and the limited pick up on the policy side. The panel suggested the time may be ripe for developing a realistic time line to guide further Roadmap work. The panel noted that many fish stocks under NAFO's responsibility are still in a precarious state, in some cases largely because of ecosystems change, including the impacts of climate change (NAFO 2018c).

NAFO has not developed clear criteria for allocating fishing opportunities in the Regulatory Area with NAFO's Convention providing limited guidance. Article VI (12) requires the Commission to take into account the interests of contracting parties whose vessels have traditionally fished within the area and the interests of the relevant coastal states. In allocations of fishing opportunities from the Grand Bank and Flemish Cap, the Commission must give special consideration to the contracting parties whose coastal communities are primarily dependent on fishing activities for stocks relating to those fishing banks and that have undertaken extensive efforts to ensure the conservation of such stocks through international action, in particular, by providing surveillance and inspection of international fishing activities on those banks under an international scheme of joint enforcement (NAFO 2017a). No mention is made of the fish stock distribution factor.

NAFO has confronted one major species shift needing to be addressed, namely the movement of pelagic oceanic redfish (Sebastes mentella) into the NAFO Regulatory Area from its traditional restriction to an area regulated by the North-East Atlantic Fisheries Commission (NEAFC; Rayfuse 2019). The range expansion of pelagic oceanic redfish has been linked to warming waters linked to climate change (NAFO 2001 $a$ ). Debates continue on whether the pelagic redfish is part of a single transboundary stock or a component of up to four biological stocks occurring in the Irminger Sea off western Iceland and adjacent waters (Cadrin et al. 2010, Shum et al. 2015). A NAFO/ NEAFC Working Group on Oceanic Redfish first discussed management options back in 2001 but could not reach agreement on how best to address the shared stock (NAFO 2001 $a$, Thomson 2003). At a subsequent 2001 meeting of NAFO's Fisheries Commission, an ad hoc management arrangement was agreed to whereby the NAFO Convention Area quota would be 30,000 tonnes, which would be deducted from the overall quota set by NEAFC of 95,000 tonnes (NAFO 2001b). The practice of the NEAFC setting overall quotas for the pelagic redfish fishery in the Irminger Sea and adjacent areas but setting aside an allocation for NAFO was continued in following years (e.g., NEAFC 2004, 2010). From 2011 to 2019, NEAFC has prohibited catches of shallow pelagic redfish in the Irminger Sea and adjacent waters (NEAFC 2011, 2019) with NAFO being informed of the prohibition. NAFO has followed suit by not allowing harvesting of redfish from the shared stock (NAFO 2011, 2019a). NAFO and NEAFC cooperation in managing pelagic redfish might be best described as "informal" and based on yearly practice without a formal agreement or memorandum of understanding that clarifies the management process.

International Commission for the Conservation of Atlantic Tunas ICCAT, established under the 1966 Convention for the Conservation of Atlantic Tunas (ICCAT 2019a), has a broad geographical and species mandate. The ICCAT Convention Area covers the entire Atlantic Ocean including its adjacent seas, such as the Mediterranean, and encompasses areas under national jurisdiction as well as the high seas (Russell 2010). ICCAT includes more than 30 tuna and tuna-like species under its management umbrella, which includes large and small tunas, swordfish, marlins, sailfish (Russell 2010), and a range of shark species (ICCAT 2016).

ICCAT has developed a system for providing scientific advice. The Standing Committee on Research and Statistics (SCRS) is the main scientific advisory body to the Commission and has four panels (ICCAT 2016). Panel 1 addresses tropical tunas (yellowfin [Thunnus albacares], bigeye [T. obesus], and skipjack [Katsuwonus pelamis ]). Panel 2 addresses northern temperate tunas (albacore [T. alalunga] and Atlantic bluefin [T. thynnus]). Panel 3 addresses southern temperate tunas (albacore and southern bluefin [ $T$. maccoyii]), while Panel 4 deals with other species (swordfish [Xiphias gladius], billfishes, and small tunas). SCRS work is further supported by various species groups and other working groups (ICCAT 2016).

A 2016 performance review of ICCAT identified a range of scientific limitations (ICCAT 2016). ICCAT does not have an independent, external science provider but depends mainly on scientists from contracting parties and cooperating nonparties and entities. Concerns have been raised about the ability of national scientists to speak freely about issues in their country's fisheries (ICCAT 2016). Modeling scientists with quantitative skills have dominated SCRS meetings without a balance of scientists with broader knowledge of fisheries. With few exceptions, fishing independent data on stock size and fishing mortality is not collected (ICCAT 2016). ICCAT has several research programs, such as the Atlantic-Wide Research 
Programme for Bluefin Tuna (GBYP) and the Atlantic Ocean Tropical Tuna Tagging Programme (AOTTP) but ensuring medium- and long-term financial support is an ongoing concern (ICCAT 2016).

Although ICCAT's failure to heed scientific advice and poor management record over past decades is well documented (Russell 2010, Saunders and Haward 2016), ICCAT has progressed on some fronts. Agreement was reached to substantially amend ICCAT's convention, which will mandate precautionary and ecosystem approaches (ICCAT 2019b, c). Amendments were adopted at ICCAT's annual meeting in November 2019 (ICCAT 2020). Even though several stocks remain overfished, such as bigeye tuna and swordfish in the Mediterranean, most stocks subject to rebuilding programs, specifically western bluefin tuna, eastern bluefin tuna, northern albacore, and northern swordfish, are improving or within safe biological limits (ICCAT 2016).

Climate change continues to receive minimal attention from ICCAT. ICCAT's Sub-Committee on Ecosystems is tasked with addressing how to implement ecosystem-based fisheries management, but the focus has largely been on estimating and reducing bycatches of sea turtles, seabirds, marine mammals, and sharks (e.g., ICCAT 2018a, 2019d). The Sub-Committee has been developing an Ecosystem Report Card for ICCAT but the Report Card has yet to be finalized with ongoing discussions regarding the most appropriate environmental indicators (Kell and Luckhurst 2018, Juan-Jordá et al. 2018b) and ecoregions (ICCAT 2019d). The Standing Working Group to Enhance Dialogue between Fisheries Scientists and Managers (SWGSM), first meeting in 2014, offers a potential forum to explore climate change issues specifically. However, the SWGSM has largely focused on identifying harvest control rules and trying to advance the application of management strategy evaluation (MSE) for priority stocks, northern albacore, North Atlantic swordfish, bluefin tuna, and tropical tunas (ICCAT 2018b).

ICCAT has published scientific papers that highlight how climate change may be impacting marine ecosystems and tuna fisheries. For example, one study flagged the numerous uncertainties surrounding climate change on tuna and the special vulnerabilities of Atlantic bluefin in particular, such as loss of suitable spawning grounds in the Gulf of Mexico with projected rising ocean temperatures (Muhling et al. 2014).

A number of research studies have noted the substantial mixing of bluefin tuna stocks from the western and eastern Atlantic (Alemany et al. 2018, Carruthers and Butterworth 2018). However, ICCAT continues to quite arbitrarily manage bluefin tuna stocks as two populations (western and eastern / Mediterranean) with a $45^{\circ}$ west meridian boundary (Di Natale 2018). Limited scientific monitoring and understanding of bluefin tuna adaptive behaviors and distributions continues to be emphasized (Di Natale et al. 2020).

ICCAT has adopted allocation criteria for fishing possibilities through Resolution 15-13 that could factor in climate change shifts in distributions and abundance. Specific consideration may be given to the distributions and biological characteristics of stock (s), including the occurrence of stock(s) in areas under national jurisdiction and on the high seas. Other criteria include historical catch levels; interests of artisanal, subsistence, and small-scale fishers; needs of coastal fishing communities; needs of coastal states in the region; and socioeconomic dependence by developing states in the region.

Ocean warming has in fact raised a new fisheries governance challenge with Atlantic bluefin migrating farther north off eastern Greenland. Migration is believed to be linked to the rising ocean temperature off eastern Greenland and the migrations of key prey, especially mackerel, into the region (MacKenzie et al. 2014, Jansen et al. 2016; Jansen 2019, personal communication). A reported 84 bluefin tunas have been taken as bycatch since 2012 (Jansen et al. 2020). Greenlandic catches raise substantial governance challenges. Denmark on behalf of Greenland is not a party to ICCAT, and the future role of ICCAT, if any, has yet to be determined.

\section{Canada-United States management of Georges Bank shared groundfish}

Following a 1984 International Court of Justice (ICJ) ocean boundary decision, which gave both countries a portion of the rich Georges Bank fishing ground (ICJ 1984), Canada and the United States were faced with the need to develop cooperative arrangements especially to prevent overexploitation of three important commercial fish stocks that were shared: cod, haddock (Melanogrammus aeglefinus), and yellowtail flounder (Pleuronectes ferruginea; Pudden and VanderZwaag 2010). Other than a 1990 Fisheries Enforcement Agreement, which bolstered surveillance and fisheries enforcement measures on Georges Bank, bilateral cooperation has been informal (Pudden and VanderZwaag 2010). A Canada-U.S. Transboundary Resources Steering Committee was established in 1995 and, meeting biannually, the Committee serves as the overall discussion forum for coordinating transboundary fisheries management (Government of Canada [date unknown]a). In 1998, the Steering Committee established the Transboundary Resource Assessment Committee (TRAC) to provide scientific advice on the status of shared cod, haddock, and yellowtail flounder stocks and to suggest appropriate catch levels (Government of Canada [date unknown]b). The Transboundary Management Guidance Committee (TMGC), established in 2000 and comprising government-industry representatives from both countries, is the main vehicle for deciding on harvest strategies and how to address resource sharing (Government of Canada [date unknown]c).

In 2001, the TMGC agreed on the resources sharing formula, which promises to be conducive to addressing changing fish stock distributions linked to climate change (Government of Canada [date unknown]d). The sharing formula, first applied in 2003, is based on both historical catches (1967-1994) and geographical distribution of the stocks. Over a seven-year period, the sharing initially weighted at $60 \%$ for resource distribution and $40 \%$ for historical landing, shifted to $90 \%$ resource distribution and $10 \%$ historical landing. Annual resource distributions are calculated based on three bottom trawl surveys.

The status of Georges Bank cod and yellowtail flounder remains very poor. Combined Canada/U.S. catches of cod in 2007 were 526 tonnes, whereas catches averaged 17,200 tonnes between 1978 and 1993 and peaked at 26,463 tonnes in 1982 (TMGC 2018). Catches of yellowtail flounder declined to 95 tonnes in 2017, whereas catches averaged 6300 tonnes during 2002-2004 and peaked at 21,000 tonnes in both 1969 and 1970 (TMGC 2018). 
Both Georges Bank cod and yellowtail flounder continue to be listed by the U.S. National Oceanic and Atmospheric Administration (NOAA) in its annual reports to Congress on the status of U.S. fisheries as subject to overfishing and being overfished (NOAA Fisheries 2017, National Marine Fisheries Service 2019).

Scientists have "sounded the siren" on the possible role of rapid warming of ocean temperature to the collapse of the Gulf of Maine (GOM) cod fishery, which is adjacent to Georges Bank (Pershing et al. 2015). Between 2004 and 2013 the GOM warmed faster than $99.9 \%$ of the global ocean.

Surprisingly, climate change has received scant attention from Georges Bank transboundary management. TRAC has given no explicit consideration to climate change in the provision of scientific advice and in its recommendations for annual quotas, although TRAC scientists have indicated water temperature changes may be playing a role in the lack of cod recovery on Georges Bank (Transboundary Resources Steering Committee 2016) and TRAC scientists have noted that low productivity of yellowtail flounder may be linked to environmental factors (TRAC 2018a). In 2011, the Transboundary Resources Steering Committee dissolved two working groups that held promise to address broader ecosystem factors, the Fish Habitat Working Group and the Oceans Working Group (Government of Canada [date unknown]e). At the September 2014 Canada-U.S. Transboundary Resources Steering Committee meeting, the Canadian cochair suggested that climate change become a standing agenda item for future meetings, but that suggestion has not been followed (Transboundary Resources Steering Committee 2014).

The TMGC has been forced to reduce cod and yellowtail quotas in recent years but without discussion of precautionary or ecosystem approaches and the possible impacts of climate change. The cod quota for the 2019 fishing year was set at 650 tonnes, a $32 \%$ reduction from 2018 and within the catch advice of TRAC (TMGC 2018). The yellowtail flounder quota for 2019 was set at 140 tonnes, the lowest yellowtail quota on record and a $53 \%$ reduction from 2018. However, the yellowtail quota was well above the 68 tonnes quota recommended by TRAC (TMGC 2018).

Eastern Georges Bank haddock has fared much better than cod and yellowtail flounder but without an explanation of why. Total biomass indices reached record highs in 2015 and 2016 surveys but have since decreased (TRAC 2018b). The TMGC set a haddock quota of 30,000 tonnes for the 2019 fishing year and that quota again was agreed to for the 2020 fishing year (TMGC 2018, 2019).

The distribution of the three Georges Bank groundfish have shown considerable annual fluctuations. The application of resource sharing formula, which may indirectly capture climate change shifts (VanderZwaag et al. 2017), shows no drastic shifts. For example, Canadian shares of cod were $75 \%$ in 2010 (Busawon et al. 2015), 81\% in 2015 (TMGC 2014) and 71\% in 2019 (TMGC 2018). Canadian shares for haddock were $59.5 \%$ in 2010 (Busawon et al. 2015), 52\% in 2015 (TMGC 2014), and 50\% in 2019 (TMGC 2018). Canadian shares of yellowtail flounder were $36 \%$ in 2010 (Busawon et al. 2015), 31\% in 2015 (TMGC 2014), and 24\% in 2019 (TMGC 2018).

\section{NORTH PACIFIC}

\section{North Pacific Fisheries Commission}

The NPFC is a new intergovernmental organization established in 2015 by the Convention on the Conservation and Management of High Seas Fisheries Resources in the North Pacific (NPFC Convention). The consultations to establish the organization began in 2006 following the UN General Assembly (UNGA) resolutions urging states to take action to protect VMEs in the deep sea from destructive fishing practices and ensure sustainability of deep sea fisheries (UNGA 2004, 2005, 2006, Moon 2016).

NPFC covers the high seas of the North Pacific Ocean except for "the high seas areas of the Bering Sea and other high seas areas that are surrounded by the exclusive economic zone of a single State" (Article 4). The southern border follows approximately $20^{\circ}$ north latitude and extends to around $10^{\circ}$ north latitude around Hawaii (NPFC [date unknown]a). It has seven contracting parties: Canada, China, Japan, Korea, Russia, the United States, and Vanuatu; Chinese Taipei is participating as a Fishing Entity (NPFC [date unknown] $b$ ).

NPFC's stated objective is to "ensure the long-term conservation and sustainable use of the fisheries resources in the Convention Area while protecting the marine ecosystems of the North Pacific Ocean in which these resources occur" (Article 2). "Fisheries resources" is a defined term that captures all marine species except sedentary species that are subject to sovereign rights of coastal states under the United Nations Convention on the Law of the Sea (UNCLOS); indicator species of VMEs under the NPFC Convention; catadromous species, marine mammals, marine reptiles, and sea birds in addition to other marine species already covered by an international fisheries management agreement (Article 1(h)). Scientific and management efforts are focused on eight species of commercial importance: North Pacific armorhead (Pentaceros wheeleri), splendid alfonsino (Beryx splendens), Pacific saury (Cololabis saira), neon flying squid (Ommastrephes bartrami), Japanese flying squid (Todarodes pacificus), chub mackerel (Scomber japonicus), spotted mackerel (Scomberomorus munroi), and Japanese sardine (Sardinella zunasi; NPFC [date unknown]c). Pelagic fisheries using dip nets or lift nets and trawl, gillnet, and longline fisheries for bottomdwelling species on seamounts are common in the Convention Area (NPFC [date unknown]d).

The Commission relies on the advice and recommendations of the Scientific Committee to achieve the objectives of the Convention (Article 6). The work of the Scientific Committee is guided by the terms of reference and includes identifying issues that warrant scientific investigation, collecting and analyzing data, providing analysis of alternative conservation and management measures, developing the criteria for identifying VMEs, as well as giving other scientific advice as the Commission considers appropriate or needed (Article 10(a), (c), (i)-(k)).

There is a general recognition within NPFC that climate change needs to be considered. NPFC is building a collaborative relationship with the North Pacific Marine Science Organization (PICES), an intergovernmental organization that coordinates scientific research into the interactions between the ocean, land, and atmosphere and their effects on marine living resources and human activities. Climate change figures prominently in PICES's 
research agenda (PICES [date unknown]). The two organizations have agreed on the NPFC-PICES Framework for Enhanced Scientific Collaboration in the North Pacific with climate change considerations incorporated into the three priority areas of work namely, (i) support for stock assessment for priority species; (ii) vulnerable marine ecosystems; and (iii) ecosystem approach to fisheries (NPFC 2019). NPFC also has co-sponsored PICES symposia and workshops (NPFC 2018a), including the one on the influence of environmental factors on species distribution shifts (NPFC 2019). The NPFC Secretariat participated in the FAO workshop on potential impacts of climate change on deepsea ecosystems and implications for deep sea fisheries management (NPFC 2017a). A working group on Pacific saury in its preparation for the stock assessment identified climate change as one of the uncertainties (NPFC 2014), while climate variability was identified as a factor that needs to be considered in setting reference points for the upcoming MSE process (NPFC 2019)

Despite the cooperation and the fact that scientists anticipate changes on the surface to impact deep water communities (Glover and Smith 2003, Polovina et al. 2008, Rogers 2015) with coldwater corals being particularly vulnerable (Rogers 2015), climate change is not mentioned in the current NPFC research plan (NPFC [date unknown]c). The research plan prioritizes (1) stock assessments for target fisheries and bycatch species; (2) ecosystem approach to fisheries; (3) VMEs; and (4) data collection, management, and security (NPFC [date unknown]c). There could be an opportunity to incorporate climate change considerations under the heading of ecosystem approach to fisheries because its areas of work includes ecosystem modeling and other issues related to marine ecosystems. Also, it may be possible to include variables that track changes in the ecosystems into the data collection program being developed by the Scientific Committee.

Under Article 3(c) of the NPFC Convention, management and conservation measures are to be adopted and implemented in accordance with the precautionary approach and an ecosystem approach to fisheries. So far, these principles are being implemented in order to protect VMEs through the closure of some seamounts to fishing, a move on rule if more than $50 \mathrm{~kg}$ of cold water corals are encountered, and an exploratory fisheries protocol (NPFC 2017b, 2018b, 2019). Protecting VMEs is a priority in NPFC but the current criteria for identifying VMEs do not explicitly include climate change (NPFC 2017b, 2018b). Instead, the criteria look at (a) uniqueness or rarity of an ecosystem; (b) functional significance of the habitat; (c) how fragile it is to anthropogenic activities; and (d) whether lifehistories of the ecosystem species make recovery difficult (NPFC 2017b, 2018b). Criterion (c) has been narrowly defined as "the likelihood that a population, community or habitat will experience substantial alteration by fishing activities and how much time will be required for its recovery from such alteration" missing an opportunity to anticipate climate change impacts (Gianni et al. 2016, NPFC 2017b:Annex 2, para 3(2), NPFC 2018b:Annex 2, para 3(2)).

\section{Western and Central Pacific Fisheries Commission}

The WCPFC was established by the Convention on the Conservation and Management of Highly Migratory Fish Stocks in the Western and Central Pacific Ocean (Art. 5, 6). The WCPFC
Convention was one of the first agreements negotiated following the adoption of the UN Fish Stocks Agreement, and it incorporates the precautionary and the ecosystem approach to fisheries with measures based on the best available scientific evidence (Articles 5 and 6; WCPFC [date unknown]a). The WCPFC is responsible for highly migratory fish stocks over a large area of the Pacific stretching as far south as $60^{\circ}$ south latitude and all the way north to the Bering Sea (Article 3(1)). The WCPFC also has the mandate to manage all the migratory species listed in UNCLOS Annex I as well as any other species the Commission may find relevant, except sauries (Articles 1(f) and 3(3)). To date, the WCPFC has focused its management on the commercially valuable species of tuna and billfish namely bigeye, skipjack, north Pacific and south Pacific albacore, yellowfin, Pacific bluefin (Thunnus orientalis), north Pacific swordfish, and north Pacific striped marlin (Tetrapturus audax). The 26 members and 7 participating territories of the Commission have to adopt domestic measures that are compatible to the measures agreed upon for the high seas ensuring consistency across the species' range (Articles 7(1) and 8(1); WCPFC [date unknown] $b$ ).

The organizational structure of the WCPFC reflects the biological range of the managed species as well as a political compromise between the north Pacific and south Pacific coastal states (WCPFC 2003, Wold et al. 2015). However, the implementation of the resulting mechanism has been wrought with uncertainties and conflict casting doubt on the Commission's ability to employ the ecosystem approach and to respond to climate-related shifts in species distribution in a timely and effective manner (Ault et al. 2013, Wold et al. 2015). The WCPFC Convention establishes three subsidiary bodies: the Technical and Compliance Committee, the Scientific Committee (SC), and the Northern Committee (NC) $)^{[1]}$ (Articles 11(1) and 11(7)). This discussion focuses on the NC and SC.

The NC has specific responsibilities for the Convention Area north of $20^{\circ}$ north latitude. It is tasked with making recommendations to the Commission "on the implementation of such conservation and management measures as may be adopted by the Commission for the area north of the $20^{\circ}$ parallel of north latitude" (Article 11(7)). This provision captures the northern range of yellowfin, skipjack, and bigeye tunas that occur predominantly in tropical waters (WCPFC 2003). The NC is also responsible for formulating conservation and management measures for northern stocks and recommending them to the Commission (Article 11(7)). The Commission has to make its decision based on the NC's recommendation, but it also has authority to reject a recommendation and return it to the NC for reconsideration (Article 11(7)). At the Thirteenth Regular Meeting of the WCPFC Commission, the NC was criticized for not going far enough to rebuild Pacific bluefin tuna. When WCPFC members failed to reach a consensus on whether to adopt the NC's recommendations, the NC held an extraordinary meeting on the sidelines and agreed on additional measures that were subsequently adopted by the Commission (WCPFC 2016a). The NC membership is restricted to coastal states and states that fish north of $20^{\circ}$ north latitude namely Canada, Chinese Taipei, Japan, Korea, Mexico, China, and the United States (Article11 (7); ISC [date unknown]). All other WCPFC members are allowed to participate as observers (Article 11(7)). 
The Scientific Committee is open to all members of the Commission, and its job is to identify and address the Commission's research needs; review assessments, analysis, and recommendations prepared for the Commission by scientific experts; research and report to the Commission on the status of stocks and species in the Convention Area; and to make recommendations on conservation, management, and research of stocks and species in the Convention Area (Articles 11(2) and 12 (2)(a),(b),(d),(e),(g)). Because the SC is responsible for sciencerelated activities in the Convention Area as a whole, it has responsibilities that overlap with the NC's duties toward northern stocks and species (Articles 11(7) and 12(2); WCPFC 2007a). To complicate matters further, the Commission has two external science providers. The Scientific Committee for Tuna and Tunalike Species in the North Pacific Ocean (ISC) was established specifically to work with the NC (WCPFC 2005a, Wold et al. 2015), while the Pacific Community Oceanic Fisheries Programme (SPC OFP) advises WCPFC in general (WCPFC $2016 b$ ). Ambiguity over which organization has the final say with respect to science and management of the northern stocks remains unresolved and the need to clarify the roles further was noted by the Performance Review Panel (WCPFC 2012a). Furthermore, members of the Commission have been unable to agree on the application of the designation criteria for northern stocks and, as a result, failed to adopt management measures for striped marlin and blue shark (Prionace glauca).

Northern stocks have been broadly defined as stocks "which occur mostly in the area north of $20^{\circ}$ north parallel" (WCPFC 2018a: Annex I, rule 2). So far, the parties have agreed to designate Pacific bluefin tuna, north Pacific albacore, and north Pacific swordfish as northern stocks. Pacific bluefin is the most valuable and the most depleted stock managed by the NC. A single stock of this species is found through the North Pacific Ocean and according to the 2016 stock assessment, it is overfished and continues to be subject to overfishing, with the spawning biomass near a historic low of about $2.6 \%$ of unfished biomass (ISC 2016). A multiyear rebuilding plan is in place (WCPFC 2018b) and the 2018 stock assessment update showed signs of recovery, although there is uncertainty in the estimated above-average recruitment in the terminal year (WCPFC 2018c). In light of the good news, the members agreed to allow a carry forward of $5 \%$ of the unfished quota (WCPFC 2018b, $d$ ) and subsequently increased the allowed carry forward to $17 \%$ (WCPFC 2019a). The NC has been coordinating its Pacific bluefin management with the InterAmerican Tropical Tuna Commission (IATTC) through a joint working group seeking to achieve consistency across the species range (WCPFC 2018c). The MSE process for Pacific bluefin also has been started and ensuring that management strategies are responsive to environmental variability has been identified as one of the purposes of the process (ISC 2018). However, the MSE is in the initial stages, and it remains to be seen how climate considerations will be addressed throughout the process in practice (ISC 2019). North Pacific albacore is considered to be a healthy stock. No specific management measures are in place, but the MSE process for this stock has been started as well (WCPFC 2005b, ISC 2017, 2018, WCPFC 2019a). It is questionable if the current process is responsive to climate change because the simulation model does not explicitly incorporate the albacores' migration rates (ISC 2019: Annex 6) The Western and Central
North Pacific Ocean stock of swordfish is also considered to be in good shape (WCPFC 2018c, 2019a). The NC members are having difficulties agreeing on a management framework and the adopted harvest strategy remains skeletal (WCPFC 2018c, 2019a). The IATTC and WCPFC share the responsibility for the Eastern Pacific Ocean swordfish, with the majority of this stock occurring in IATTC's area (Tagami et al. 2014). This stock is not overfished, but likely is experiencing overfishing, and it does not appear that any management measures are being taken to address this (WCPFC 2018c).

Although the above three species were designated as northern stocks without controversy, the 12-year debate over whether striped marlin qualifies as a northern stock highlights the deficiency of the designation criteria and a lack of cooperation between the subsidiary bodies and their scientific providers. Concern over the conservation status of striped marlin was raised in 2007 when a stock assessment estimated spawning stock biomass at $14-15 \%$ of the 1970 level and anticipated it to decline unless mortality was reduced (WCPFC 2007b). However, because of a disagreement between the NC, ISC, and SC over the species distribution relative to $20^{\circ}$ north latitude, it remains undecided which subsidiary body should be responsible for developing a rebuilding plan (WCPFC 2017, 2018d, 2019b). The uncertainty over the northern stock designation criteria is also relevant to the management of north Pacific blue shark, a valuable and vulnerable target species (WCPFC 2015). The ISC is reluctant to become involved in the designation process given its unsuccessful experience with striped marlin (WCPFC 2016c). At the NC meeting in 2016, the Secretariat suggested that criteria for designation should be developed first, and then additional research conducted. Instead, the NC recommended that WCPFC decide if north Pacific blue shark is a northern stock based on the available information. Without conclusive data on the shark's distribution, the status of this species as a northern stock remains unresolved (WCPFC 2017, 2018d). A northward expansion of low-latitude species and high-latitude fishes expanding poleward in the North Pacific Ocean is anticipated due to climate change (ISC 2014a). This is likely to create further uncertainty and management problems unless the criteria for northern stock designation are clarified.

Despite the ecosystem mandate, management measures in the North Pacific rely on a single species approach with ecosystem considerations addressed by adopting conservation and management measures on mitigation for vulnerable species such as sharks, cetaceans, sea turtles, and sea birds. The WCPFC Performance Review recommended expanding data collection to provide current data on interactions between fisheries and the ecosystem as well as on mitigation of fisheries-related risks (WCPFC 2012a). Development of a climate change research plan is not mentioned in the recommendations.

Nevertheless, at the Sixteenth Regular Meeting of the WCPFC Commission, members adopted a comprehensive resolution on climate change agreeing on the following actions (WCPFC 2019c:1-2):

1. Consider the potential impacts of climate change on highly migratory fish stocks in the Convention Area and any related impacts on the economies of CCMs [members, cooperating nonmembers, and participating 
territories] and food security and livelihoods of their people, in particular Small Islands Developing States and Participating Territories.

2. Support further development of science on the relationship between climate change and target stocks, non-target species, and species belonging to the same ecosystem or dependent on or associated with the target stocks, as well as interrelationships with other factors that affect these stocks and species, and estimates of the associated uncertainties.

3. Take into account in its deliberations, including in the development of conservation and management measures, scientific information available from the Scientific Committee on the potential impacts of climate change on target stocks, non-target species, and species belonging to the same ecosystem or dependent on or associated with the target stocks.

4. Consider how climate change and fishing activitiesmay be related and address any potential impacts in a manner consistent with the Convention.

5. Consider options to reduce the environmental impacts of the Commission related to headquarters operation and meetings of the Commission and its subsidiary bodies.

Both the ISC and SPC OFP are already adjusting their stock assessment models to reflect ecosystem considerations and climate change. Starting in 2014, the ISC has been discussing a greater collaboration with PICES (ISC 2014b).The relationship between ISC and PICES was formalized in 2016 when the two organizations approved a joint working group to assess the impact of climate change on highly migratory species, including incorporating climate change into stock assessments and management advice (ISC 2016, 2018). The ISC has also cosponsored a PICES symposium on the effects of climate change on transitional zones in the Pacific and their biological communities (ISC 2017). The SC is supporting development of the Spatial Ecosystem and Population Dynamics Model (SEAPODYM) by SPC OFP that is being "developed for investigating spatial tuna population dynamics, under the influence of both fishing and environmental effects" (Lehodey et al. 2014:2). One of the uses of the model is to help national and international tuna managers in the WCPFC to make decisions in the changing climate (WCPFC 2012b). It was mentioned during the 2012 SC meeting that the SEAPODYM program included development of swordfish application and calibration for both north and south albacore populations. Swordfish and north albacore stocks are under the purview of the NC. It was also reported to the SC that the Apex Predators ECOSystem Model Estimation (APECOSM - E) "has been developed to the extent that it could be now used to simulate climate change impacts on tuna in the Pacific Ocean" (WCPFC 2014:592). Differences between APECOSM-E and SEAPODYM provide for an opportunity to test sensitivity of the models to climate change scenarios (WCPFC 2014).

\section{International Pacific Halibut Commission}

A single stock of Pacific halibut (Hippoglossus stenolepis) inhabits the waters off the west coast of North America from Alaska to northern California, with the center of abundance around Kodiak
Island (Clark and Hare 2006). Canada and the United States first entered into an agreement to cooperate on the management of Pacific halibut in 1923 (IPHC [date unknown] a). The Convention for the Preservation of the Pacific Halibut Fishery was updated several times to incorporate developments in fisheries management and conservation, with the latest amendment coming in 1979. The Protocol Amending the Convention between the United States of America and Canada for the Preservation of the Halibut Fishery of the Northern Pacific Ocean and Bering Sea (Protocol) implemented the exclusive economic zones and phased out reciprocal fishing privileges (Protocol, Annex I, Article 1; McCaughran and Hoag 1992).

The IPHC continues the work of the International Fisheries Commission established in 1923 with the primary objective of developing and maintaining halibut stocks at levels that permit optimum yield from the fishery in the waters under national jurisdiction off the west coast of the United States and Canada from California to Alaska (Protocol Articles 1(2), 1(3), 2(1)). The IPHC Convention Area is divided into four biological regions: 2 , 3, 4, and 4B (IPHC 2019a). These regions are further subdivided into regulatory areas. Area $2 \mathrm{~A}$ covers California, Oregon, and Washington; Area 2B is British Columbia; and Area 2C is in southeastern Alaska (IPHC 2019a). Areas 3A and 3B divide the Gulf of Alaska; and Areas 4A through 4E cover the Aleutian Islands and the Bering Sea (IPHC 2019a). The IPHC is assisted in its work by five advisory bodies, including the Research Advisory Board, where members of the halibut fishing community provide input on the direction of the IPHC research program; the Management Strategy Advisory Board (MSAB), which oversees the MSE process; and the Scientific Research Board tasked with providing peer review of the IPHC science and stock assessments (IPHC [date unknown] b). Commercial, sport, and traditional fishers as well as fishers who incidentally catch halibut in the Convention Area have to follow the Pacific Halibut Fishery Regulations (IPHC 2019a). The Regulations are amended at the annual meeting and outline fishery rules such as annual catch limits, size limit, licensing requirements, regulatory area boundaries and closed areas, gear restrictions, release guidelines, and logbook instructions.

Although Pacific halibut has been recognized as one of the bestmanaged stocks (McCreary and Brooks 2012), the fishery is experiencing difficulties. Since 2017 the Commission adopted "an informal 'fish-down"' strategy based on its stock assessments (IPHC 2017a: 6, 2018a: 6, 2020a: 6). This strategy allows reduction in the average age and size of a stock being fished for the first time. As a result, current catches are maintained, but only as long as there are sufficient older fish in the fishery (IPHC [date unknown]c). The IPHC scientists are projecting a decrease in the stock biomass between 2019 and 2023 because of smaller cohorts moving through the fishery (IPHC 2018a, 2020a). It is unclear whether observed decreases in stock biomass are part of the known pattern or signal an uncharted territory due to climate change (IPHC 2018a).

Sensitivity of Pacific halibut to environmental variability is known to IPHC scientists. Pacific halibut spend summer months in shallow coastal waters and migrate into deeper waters offshore in the winter to spawn (Clark and Hare 2006). Eggs and larval fish then drift in the surface layer westward and northward for 
six to seven months (Beamish 2008). The strength of the year class is determined by the climate and ocean conditions during this drifting phase (Beamish 2008). In fact, the long-term data demonstrates variations in growth, recruitment, and distribution of halibut in response to changes in climate, such as the ones driven by the Pacific Decadal Oscillation, a pattern with approximate frequency of 30 years (Hare 2004, Beamish 2008). The resulting difference in size is significant given that in 1980 an 11-year-old female halibut landed in Alaska averaged 40 pounds and less than 20 pounds in 1995 (Hare 2004). Halibut distribution also continuously changes over different time and scale. For example, over the last decade, an increasing proportion of the stock has been found in Region 2 while the proportion has been decreasing in Region 3 (Stewart and Webster 2017). Over the last five years the distribution has been relatively stable, but between 2016 and 2017 the relative biomass in regulatory areas 2A, 2B, and $3 \mathrm{~B}$ decreased in relation to all other areas (Stewart and Webster 2017).

The IPHC is investing significant resources into understanding the mechanism of climate-halibut interaction. The IPHC Secretariat employs full time and seasonal scientific staff to conduct data collection, quantitative analysis, biological and ecosystem research, as well as work in economics and policy (Protocol Article 3(2), IPHC [date unknown]d). This work allows IPHC scientists to conduct annual stock assessments that are used to inform management decisions (IPHC [date unknown]e). In the 2017-2021 Research Program, the Research Advisory Board prioritized the following activities: identify critical knowledge gaps in the biology of Pacific halibut; understand the influence of environmental conditions on halibut biology (growth and sex determination); and apply resulting knowledge to reduce uncertainty in stock assessment models (Planas 2016, IPHC $2016 a$ ). One project is looking into growth-related physiological changes in response to environmental variability (IPHC [date unknown]f). This research is intended to address uncertainty around the observed size declines in Pacific halibut. Another project is incorporating data collected from near-bottom water column profilers into the spatial model being developed for stock assessments (IPHC [date unknown]g). The IPHC has a long history of collaboration with PICES with the relationship formalized in a memorandum of understanding in 2000 (IPHC 2017b). The IPHC has participated and cosponsored several climate change-related conferences and publications, as well as provided data and analysis to the North Pacific Ecosystem Status Report (IPHC 2017b). A workshop on climate variability and changes in the distribution of flatfish was scheduled for the 2020 PICES Annual Meeting (IPHC 2020b).

The IPHC has been engaged in MSE since 2013 (IPHC [date unknown] $h$ ). Answers to the questions that are being investigated through the MSE process should help the organization incorporate climate change considerations in halibut management. The process is overseen by the MSAB, which has representatives from the industry, fisheries management, and academia, with the goal of making MSE an interactive process between scientists and stakeholders (IPHC [date unknown] $h$, IPHC 2017a). Environmental variability is being incorporated into the operating model, the simulation framework and assumptions, as well as plausible scenarios for investigation in the MSE process (IPHC 2018b, IPHC 2019b). To improve accuracy, the MSAB has requested that the Secretariat provide it with a report on research activities that look into the effects of environmental conditions on halibut populations (IPHC 2019b). In particular, the MSAB is interested in research on (a) migration patterns, stock structure, and consequences to area productivity, (b) productivity by region, and (c) climate drivers of Pacific halibut ecology and movement. MSE results will be presented to the Commission in 2021 (IPHC 2019b).

Catch allocation among the IPHC regulatory areas is one of the management questions being investigated through the MSE process (IPHC 2018a). The Commission already has experience with having to adjust allocation in response to changes in stock distribution. In 1979, when the Protocol was signed, Canada and the United States agreed to split the catch limit in the shared Region 2 at $60 \%$ to be caught in Canadian waters and $40 \%$ in the American (Protocol, Annex I, Article 3). As halibut became more abundant in American waters during the 1980s, the Commission recommended a departure from this arrangement and adopted a harvest strategy that takes a constant proportion of the exploitable biomass (McCaughran and Hoag 1992).

Catch allocation between IPHC regulatory areas is done in accordance with the harvest strategy policy based on a proportion of the exploitable spawning biomass in each regulatory area in relation to the spawning biomass of the stock coast-wide (IPHC 2018a, Hicks and Stewart 2019). Exploitable spawning biomass in each regulatory area is estimated from setline survey data, available habitat based on bottom area of the regulatory area, and adjustment factors (Cox et al. 2013, Keith et al. 2014). Annual stock assessments are used to estimate the size of the halibut stock across the Convention Area (Keith et al. 2014). By setting catch limits in each regulatory area based on its proportion of exploitable spawning biomass, IPHC aims to preserve the halibut's spatial population structure (IPHC 2019b).

Canada strongly objects to the IPHC's implementation of the apportionment methodology, arguing that it underestimates exploitable spawning biomass off the coast of British Columbia resulting in lower allowed catch in Area 2B (McCreary and Brooks 2012, IPHC 2018b). It also asserts that the United States has not adequately addressed bycatch of juvenile halibut in Alaskan groundfish fisheries resulting in inaccurate biomass calculations and catch allocations in American waters (McCreary and Brooks 2012). The disagreement culminated in 2018 when the two parties failed to reach an agreement on catch limits (IPHC 2018a). Nevertheless, both countries independently lowered their catch limits for 2018 by $11 \%$ in response to the concerning results from the annual stock assessment (IPHC 2018a).

A compromise was reached in 2019. The parties agreed on a fixed total mortality of 1.65 million pounds annually for Area 2A subject to substantive conservation concerns and a share-based allocation for Canada's Area 2B (IPHC 2019c). Canada's share is calculated based on a weighted average with $30 \%$ reflecting the current target total mortality for $2 \mathrm{~B}$ and $70 \%$ on the recent historical average share of $20 \%$ of the coast-wide catches (IPHC 2019 c). This arrangement will be in place for the period 20192022 (IPHC 2019c). MSE analysis of alternative allocation methods will be presented to the Commission in 2021 (IPHC 2018a). Unlike previous years, catch allocations in 2019 set total mortality, which includes bycatch (IPHC 2018b). This change 
provides an incentive for the parties to minimize halibut bycatch in groundfish fisheries.

As already mentioned, halibut are sensitive to environmental changes. As a result, setline survey location and depth, as well as environmental conditions during sampling, impact results and subsequent catch allocation. For example, in 2018 concerns were raised over the accuracy of the survey in $2 \mathrm{~A}$ due to the recorded hypoxia event (IPHC 2018b). The IPHC scientists are continuously evaluating their survey strategy to improve accuracy and adjusting the stock assessment model to reflect new knowledge (IPHC 2016b). But as the scientists work to remain responsive to climate-driven changes in halibut distribution, economic considerations inherent in catch allocation create a risk to stock sustainability. The 2019-2022 arrangement for regulatory areas $2 \mathrm{~A}$ and $2 \mathrm{~B}$ support this assertion. The parties agreed to fix total mortality in $2 \mathrm{~A}$, subject to substantive conservation concerns, and calculate $70 \%$ of the total mortality in $2 \mathrm{~B}$ based on Canada's average historical allocation of $20 \%$ of the coast-wide catch. This arrangement maintains consistent catch levels in the two regulatory areas but significantly restricts the managers' ability to respond to climate-driven changes in distribution.

\section{Pacific Salmon Commission}

Canada and the United States comanage the five species of Pacific salmon through the Pacific Salmon Treaty (PST), which was ratified in 1985. It was subsequently amended by the Pacific Salmon Agreement (PSA) signed in 1999 after a decade of heated negotiations (McDorman 1998, McRae 2001, Munro et al. 2001). The interception of fish spawned in Canadian waters by American fishers, and vice versa, was the main source of contention.

The PSA has 15 articles and 4 annexes. In Article 3 Canada and the United States agree to manage their fisheries and enhancement programs in a way so as to "(a) prevent overfishing and provide for optimum production; and (b) provide for each Party to receive benefits equivalent to the production of salmon originating in its waters." They further agree to "cooperate in management, research and enhancements ... [and] take into account: (a) the desirability in most cases of reducing interceptions; (b) the desirability in most cases of avoiding undue disruption of existing fisheries; and (c) annual variations in abundance of the stocks" (Articles 3(2)-(3)).

Article 2 establishes the PSC, which administers the complex system designed to ensure consistent measures in the two countries, respond to the differences in life histories among various salmon species and stocks, as well take into account differences in fisheries. Reporting obligations, management plans, objectives, goals, and allocations agreed upon by the parties are found in the seven periodically renegotiated chapters of Annex IV. Each chapter deals with a specific species or geographic location.

The seven chapters in Annex IV are implemented by five panels established in accordance with Article 2 of the Treaty and Annex I. They are advised by individual technical committees staffed by scientists who monitor, collect data, generate forecasts, and conduct research into the species and geographic area under their purview. The management of Chinook salmon has a different set up where the Chinook Technical Committee is responsible for Annex IV, Chapter 3, and it reports directly to the Commission and not a Panel (PSC [date unknown] $a$ ).
The PSC also has a Committee on Scientific Cooperation (CSC) [2] that helps advance the Commission's scientific agenda by presenting scientific information and identifying emerging issues. It also supports the technical committees when needed and assists the PSC in promoting scientific cooperation among the parties (PSC [date unknown] $b$ ).

Prior to 2016, climate change was not addressed at the PSC in a systematic manner. In 2016 the Commission asked the CSC to develop a plan to document and respond to environmental anomalies and their effects on salmon (PSC 2017). The following year the CSC released a technical report that looked into the question of extreme environmental conditions experienced in 2015 and 2016 and their effects on salmon (McKinnell 2017). It also presented to the Commission "A Strategy for Consideration of Annual Variation in Environmental Indicators and Salmon Production and its Implications for Fisheries Management under the Pacific Salmon Treaty" (Strategy) based on the findings in the technical report (PSC 2017:2). The Strategy identified four components:

\section{Improve information sharing and access to measures of environmental and biological variability, including salmon population metrics;}

2. Develop a capacity for compiling and evaluating annual variability in environmental and salmon indicators to provide an information base to assist in forecasting and managing salmon populations;

\section{Inform the Commission and its science community annually on observations of changing environmental conditions and their relation to salmon production; and,}

\section{Engage other international organizations through initiatives such as the International Year of the Salmon to enhance and leverage PSC capacity and efforts to address (1) to (3).}

The CSC annually updates the Commission on its work with respect to the Strategy. This includes working with the Secretariat on the development of an online portal to facilitate access and exchange of information on environmental variability and its effect on salmon between the PSC members (PSC 2018). A workshop on the status of salmon productivity in relation to the state of the oceans in different regions took place at the 2019 annual meeting (PSC 2019). As the need to ensure that the management framework can respond rapidly to the observed changes in the environmental and salmon conditions was raised by the PST members, presented topics included examples of incorporating environmental variation in management (PSC 2018, 2019). The Commission is also participating in the International Year of the Salmon, a five-year international initiative for collaboration in outreach and research (PSC 2019). Scheduled activities include a workshop on salmon ecology in a changing climate that will elaborate on the issues that were discussed at the PSC climate-related workshop. The CSC aims to use the gained knowledge to develop recommendations for the Commission on monitoring and adapting to environmental variability (PSC 2019).

The PSC implements an abundance-based management regime that is data intensive and highly dependent on forecasting methods to arrive at preseason estimates that inform management 
goals. Climate change introduces uncertainty into these preseason stock assessments (Plate et al. 2009). Nearly all of Pacific coast salmon growth occurs in the coastal and open waters of the North Pacific and Bering Sea (Beamish et al. 2009). Water temperature during spawning, rate of growth in natal streams, and prey availability in the ocean affect salmon survival (Beamish et al. 2009, Plate et al. 2009). To complicate matters further, there is unlikely to be consistency in the effects among species and regions with potentially different effects on the same species in different regions or opposite effects on different species in the same area (Beamish et al. 2009, Plate et al. 2009).

The provisions in the recently renegotiated chapters explicitly recognize the need to collect and share annual variations in the environment and their effects on salmon productivity among the Commission's members (PSC 2019). The CSC is developing recommendations on how to accomplish this based on the results of the 2019 workshop on climate and salmon (PSC 2019). These chapters also contain specific obligations for the Panels and Technical Committees to ensure that management measures are responsive to environmental conditions. In transboundary rivers under Chapter 1, the parties are required to conduct postseason run reconstructions and make adjustments to the management regime if the objectives are not met for three consecutive years (PST, Annex IV, Chapter 1, s. 4(a)). For the management of Chinook fisheries under Chapter 3, the parties agreed that the management measures have to be responsive to changes in Chinook salmon stocks because of environmental conditions (PST, Annex IV, Chapter 3, s. 1(b) and 2(a)(ii)). The Chinook stock assessment model is being updated to incorporate environmental conditions (PSC 2019). For the Fraser River sockeye and pink salmon, the management Panel is instructed to take into account environmental factors when setting TAC to ensure that the spawning escapement objectives are achieved (PST, Annex IV, Chapter 4, s. 3(b) and 13(b)). And finally in Chapter 5, the Technical Committee on Coho has been instructed to develop strategies, methods, and investigations to address uncertainty caused by data limitations and variation in environmental conditions to meet the objectives of the Southern Panel (PST, Annex IV, Chapter 3, s. 7(e) and (1)).

\section{CONCLUSION}

In the wake of the above Northwest Atlantic and North Pacific reviews seeking to assess the seaworthiness of eight transboundary fisheries management arrangements to address a changing ocean, three realities stand out. First, no regional or bilateral management arrangement is custom made to address climate change. No treaty or founding documents mention climate change, and no specific directions are given to include climate change threats and impacts in setting scientific research priorities and in determining management measures. The imperative to better consider climate change arises indirectly through the responsibility to implement key international principles, such as precautionary and ecosystem approaches and adaptive management (Pentz and Klenk 2017).

Second, although climate change is at least on the radar screen of all eight arrangements in terms of raising new uncertainties and challenges for fisheries management, charting new management approaches remains politically difficult. Managers continue to place their faith in single stock assessments and to focus attention on ensuring the sustainability of key commercial and, in some cases, recreational fish stocks.

Third, the seaworthiness of the eight arrangements to address climate change varies considerably. The least seaworthy appear to be the transboundary fisheries management arrangements for Georges Bank groundfish and NASCO. The informal arrangements for Georges Bank continue to largely ignore climate change and the need for an ecosystem approach. Climate change is only indirectly addressed through a quota allocation scheme that allocates $90 \%$ of the TAC based on geographical distribution of the groundfish stocks. For 2019, the yellowtail flounder quota was set almost twice above the amount recommended by scientists and in the face of serious environmental concerns. NASCO continues to have limited jurisdiction and abilities to ensure precautionary and ecosystem approaches are taken to conserve wild Atlantic salmon, and struggles continue over the management of mixed stock fisheries off St. Pierre and Miquelon and off West Greenland.

The most seaworthy appear to be NAFO and the two bilateral agreements between Canada and the United States in the Pacific. NAFO has been a leader in trying to advance ecosystem productivity and multispecies modeling, although putting the models into practice has yet to occur. For over 15 years NAFO has collaborated with NEAFC in managing a pelagic oceanic redfish stock that became shared because of a distribution shift linked to climate change. In the Pacific, both the IPHC and PSC are devoting considerable efforts to studying climate interactions with halibut and salmon stocks respectively. In both arrangements, the parties have been able to overcome competitive tactics that undermine the sustainability of stocks through recent disagreements and renegotiations.

Three arrangements can be categorized as moderately seaworthy. Although ICCAT has advanced by amending its Convention to require precautionary and ecosystem approaches and in rebuilding some of its managed stocks, it continues to give minimal attention to climate change and quite arbitrarily manages bluefin tuna stocks as two populations divided by a $45^{\circ}$ west meridian boundary. ICCAT has yet to address a new fisheries governance challenge, the migration of Atlantic bluefin off eastern Greenland, which is linked to rising ocean temperatures. Although the WCPFC operates under a modernized convention and has also supported ecosystem and population dynamic modeling, it still relies on a single species management approach and has used the uncertainty over stock distributions to avoid necessary management actions for striped marlin and blue shark. Although the NPFC is also committed to applying precautionary and ecosystem approaches pursuant to its 2015 Convention, it does not include climate change in its current research plan and an ecosystem approach has largely depended on identifying and protecting VMEs.

Whether the eight arrangements will be seaworthy in facing future climate change and ocean acidity impacts remains to be seen. Much will depend on the magnitude and pace of ecosystem changes and the ability of the arrangements to adapt (PalaciosAbrantes et al. 2020, Sumaila et al. 2020). Rough voyaging likely looms ahead as strong political pressures to retain catch shares in shifting fish species continue to confront the need for management practices to be more conservative under conditions 
of uncertainty (Rayfuse 2019). Translating precautionary and ecosystem approaches from paper into practice remain works in progress.

${ }^{[1]}$ Unlike the Technical and Compliance Committee and Scientific Committee, Article 11 of the WCPFC Convention avoids referring to the Northern Committee as a subsidiary body.

[2] Article 2(17) of the Pacific Salmon Treaty calls for the establishment of the Committee on Research and Statistics. The name of the Committee was subsequently changed to Committee on Scientific Cooperation. See Attachment D to the 30 June 1999 Agreement between the Parties.

Responses to this article can be read online at: https://www.ecologyandsociety.org/issues/responses. php/11835

\section{Acknowledgments:}

The authors wish to acknowledge research support from the Social Sciences and Humanities Research Council of Canada, through the OceanCanada Partnership grant, and from the Canada First Research Excellence Fund, through the Ocean Frontier Institute. The research facilitation by the Integrated Marine Biosphere Research (IMBeR) project is also appreciated through its convening of the 2019 IMBeR Open Science Conference in Brest, France where authors were able to share their views and initial research findings.

Data Availability:

All relevant data are provided in the article. No code was used.

\section{LITERATURE CITED}

Alemany, F., S. Temsek, and A. Pagá Garcia. 2018. ICCAT Atlantic-Wide Research Programme for Bluefin Tuna (GBYP) activity report for the last part of Phase 7 and the first part of Phase 8 (2017-2018). SCRS/2018/171. International Commission for the Conservation of Atlantic Tunas, Madrid, Spain.

Ásgeirsdóttir, A. 2019. An international relations perspective on compliance and enforcement. Pages 271-290 in R. Caddell and E. J. Molenaar, editors. Strengthening international fisheries law in an era of changing oceans. Hart, Oxford, UK. https://doi. org/10.5040/9781509923373.ch-012

Ault, J., H. Matsuda, and C. I. Zhang. 2013. Report of peer review of function. ISC/13/PLENARY/10. International Scientific Committee for Tuna and Tuna-like Species in the North Pacific Ocean.

Beamish, R. J., editor. 2008. Impacts of climate and climate change on the key species in the fisheries in the North Pacific. PICES Scientific Report No. 35. North Pacific Marine Science Organization, Sidney, British Columbia, Canada.

Beamish, R. J., B. E. Riddell, K. L. Lange, E. Farley Jr., S. Kang, T. Nagasawa, V. Radchenko, O. Temnykh, and S. Urawa. 2009.
Effects of climate change on Pacific salmon: a summary of published literature. NPAFC Special Publications No. 1. North Pacific Anadromous Fish Commission, Vancouver, British Columbia, Canada.

Busawon, D. S., H. H. Stone, L. O'Brien, and K. J. Clark. 2015. Update of allocation shares for Canada and the USA of the transboundary resources of Atlantic cod, haddock and yellowtail flounder on Georges Bank through fishing year 2016. TRAC Reference Document 2015/04. Fisheries and Oceans Canada, Ottawa, Ontario, Canada.

Cadrin, S. X., M. Bemreuther, A. K. Danielsdóttir, E. Hjórleifsson, T. Johansen, L. Kerr, K. Kristinsson, S. Mariani, K. Nedreass, C. Pampoulie, B. Planque, J. Reibert, F. SaboridoRey, T. Sigurosson, and C. Stransky. 2010. Population structure of beaked redfish, Sebastes mentella: evidence of divergence associated with different habitats. ICES Journal of Marine Science 67(8):1617-1630. https://doi.org/10.1093/icesjms/fsq046

Carruthers, T., and D. S. Butterworth. 2018. A mixture model interpretation of stock of origin data for Atlantic bluefin tuna. SCRS/2018/133. International Commission for the Conservation of Atlantic Tunas, Madrid, Spain.

Clark, W. G., and S. R. Hare. 2006. Assessment and management of Pacific halibut: data, methods, and policy. IPHC Scientific Report No. 83. International Pacific Halibut Commission, Seattle, Washington, USA.

Cox, S. P., J. Ianelli, and M. Mangel. 2013. Review of the IPHC method for apportioning halibut exploitable biomass among regulatory areas. IPHC Scientific Review Board, Meeting 1. International Pacific Halibut Commission, Seattle, Washington, USA.

DeCaro, D. A., C. A. (T.) Arnold, E. F. Boamah, and A. S. Garmestani. 2017. Understanding and applying principles of social cognition and decision making in adaptive environmental governance. Ecology and Society 22(1):33. https://doi. org/10.5751/ES-09154-220133

Di Natale, A. 2018. Due to the new scientific knowledge, is it time to reconsider the stock composition of the Atlantic bluefin tuna? SCRS/2018/122. International Commission for the Conservation of Atlantic Tunas, Madrid, Spain.

Di Natale, A., D. Macias, and J. L. Cort. 2020. Atlantic bluefin tuna fisheries: temporal changes in the exploitation pattern, feasibility of sampling, factors that can influence our ability to understand spawning structure and dynamics. International Commission for the Conservation of Atlantic Tunas, Madrid, Spain.

Dunn, C. D., G. Ortuño Crespo, and R. Caddell. 2019. Areabased fisheries management. Pages 189-218 in R. Caddell and E. J. Molenaar, editors. Strengthening international fisheries law in an era of changing oceans. Hart, Oxford, UK. https://doi. org/10.5040/9781509923373.ch-009

Engler, C. 2020. Transboundary fisheries, climate change, and the ecosystem approach: taking stock of the international law and policy seascape. Ecology and Society 25(4):43. https://doi. org/10.5751/ES-11988-250443" 
Fisheries and Oceans Canada. 2018. Review of the science associated with the Inner Bay of Fundy Atlantic salmon live gene bank and supplementation programs. Canadian Science Advisory Secretariat Science Advisory Report 2018/041. Fisheries and Oceans Canada, Ottawa, Ontario, Canada.

Gianni, M., S. D. Fuller, D. E. J. Currie, K. Schleit, L. Goldsworthy, B. Pike, B. Weeber, S. Owen, and A. Friedman. 2016. How much longer will it take? A ten-year review of the implementation of United Nations General Assembly Resolutions 61/105, 64/72 and 66/68 on the management of bottom fisheries in areas beyond national jurisdiction. Deep Sea Conservation Coalition, Amsterdam, The Netherlands. [online] URL: http:// www.savethehighseas.org/publicdocs/DSCC-Review-2016_Launch-29July.pdf

Glover, A. G., and C. R. Smith. 2003. The deep-sea floor ecosystem: current status and prospects of anthropogenic change by the year 2025. Environmental Conservation 30(3):219-241. https://doi.org/10.1017/s0376892903000225

Government of Canada. [date unknown]a. Canada-U.S. Transboundary Resources Steering Committee. Government of Canada, Ottawa, Ontario, Canada. [online] URL: https://www. bio.gc.ca/info/intercol/sc-cd/index-en.php

Government of Canada. [date unknown]b. Transboundary Resource Assessment Committee. Government of Canada, Ottawa, Ontario, Canada. [online] URL: https://www.bio.gc.ca/ info/intercol/trac-cert/index-en.php

Government of Canada. [date unknown]c. Transboundary Management Guidance Committee. Government of Canada, Ottawa, Ontario, Canada. [online] URL: http://www.bio.gc.ca/ info/intercol/tmgc-cogst/index-en.php

Government of Canada. [date unknown]d. Sharing agreement. Government of Canada, Ottawa, Ontario, Canada. [online] URL: https://www.bio.gc.ca/info/intercol/tmgc-cogst/sharing-ententeen.php

Government of Canada. [date unknown]e. Canada-U.S. Fish Habitat Working Group. Government of Canada, Ottawa, Ontario, Canada. [online] URL: https://www.bio.gc.ca/info/ intercol/sc-cd/group/fhwg-gtchp-en.php

Grafton, R. Q. 2010. Adaptation to climate change in marine capture fisheries. Marine Policy 34:606-615. https://doi. org/10.1016/j.marpol.2009.11.011

Gullestad, P., S. Sundby, and O. S. Kjesbu. 2020. Management of transboundary and straddling fish stocks in the Northeast Atlantic in view of climate-induced shifts in spatial distribution. Fish and Fisheries 21(5):1008-1026. https://doi.org/10.1111/ $\underline{\text { faf. } 12485}$

Hare, S. 2004. Pacific halibut. International Pacific Halibut Commission, Seattle, USA. [online] URL: http://meetings.pices. int/publications/special-publications/NPESR/2004/File_14_pp_221_226. pdf

Heenan, A., R. Pomery, J. Bell, P. C. Munday, W. Cheung, C. Logan, R. Brainard, A. Y. Amri, P. Alino, N. Armada, L. David, R. Rivera-Guieb, S. Green, J. Jompa, T. Leonardo, S. Mamauag,
B. Parker, J. Shackeroff, and Z. Yasin. 2015. A climate-informed, ecosystem approach to fisheries management. Marine Policy 57:182-192. https://doi.org/10.1016/j.marpol.2015.03.018

Hicks, A., and I. Stewart. 2019. Further investigation of management procedures related to coastwide fishing intensity. IPHC-2019-MSAB013-08. International Pacific Halibut Commission, Seattle, Washington, USA.

International Atlantic Salmon Research Board (IASRB). 2017. Inventory of research relating to salmon mortality in the sea (Summary only). SAG (17) 2. IASRB, Edinburgh, UK.

International Commission for the Conservation of Atlantic Tunas (ICCAT). 2016. Report of the second independent performance review. PLE-103/2016. ICCAT, Madrid, Spain.

International Commission for the Conservation of Atlantic Tunas (ICCAT). 2018a. Report of the 2018 ICCAT SubCommittee on Ecosystems meeting. Madrid, Spain, 4-8 June. ICCAT, Madrid, Spain.

International Commission for the Conservation of Atlantic Tunas (ICCAT). 2018b. Report of the fourth meeting of the Standing Working Group to Enhance Dialogue between Fisheries Scientists and Managers (SWG-SM). Funchal, Portugal, 21-29 May. ICCAT, Madrid, Spain.

International Commission for the Conservation of Atlantic Tunas (ICCAT). 2019a. Basic texts 2019 revision. ICCAT, Madrid, Spain.

International Commission for the Conservation of Atlantic Tunas (ICCAT). 2019b. Report of the 6th Meeting of the Working Group on Convention Amendment, Funchal, Portugal 24-25 May 2018. In ICCAT Report for biennial period, 2018-2019, Part I (2018) 1:291-317.

International Commission for the Conservation of Atlantic Tunas (ICCAT). 2019c. Agreed workplan to finalize the proposals for convention amendment. In ICCAT Report for biennial period, 2018-19, Part I (2018) 1:511-512.

International Commission for the Conservation of Atlantic Tunas (ICCAT). 2019d. Report of the 2019 ICCAT SubCommittee on Ecosystems meeting. Madrid, Spain, 8-12 April. ICCAT, Madrid, Spain.

International Commission for the Conservation of Atlantic Tunas (ICCAT). 2020. ICCAT Newsletter No. 31, February.

International Council for the Exploration of the Sea (ICES). [date unknown]. Working Group on North Atlantic salmon. ICES, Copenhagen, Denmark. [online] URL: http://www.ices.dk/ community/groups/Pages/WGNAS.aspx

International Council for the Exploration of the Sea (ICES). 2017. Report of the Working Group on North Atlantic Salmon (WGNAS). 29 March-7 April. ICES CM 2017/ACOM: 20. ICES, Copenhagen, Denmark.

International Council for the Exploration of the Sea (ICES). 2019. Working Group on North Atlantic Salmon (WGNAS). ICES Scientific Reports 1:16. [online] URL: http://doi. org/10.17895/ices.pub.4978 
International Court of Justice (ICJ). 1984. Delimitation of the maritime boundary in the Gulf of Maine area (Canada v. United States), [1984] ICJ Rep. 246. ICJ, The Hague, The Netherlands.

International Pacific Halibut Commission (IPHC). [date unknown] $a$. The Commission. IPHC, Seattle, Washington, USA. [online] URL: https://www.iphc.int/the-commission

International Pacific Halibut Commission (IPHC). [date unknown] $b$. IPHC structure. IPHC, Seattle, Washington, USA. [online] URL: https://www.iphc.int/the-commission/structureof-the-commission

International Pacific Halibut Commission (IPHC). [date unknown]c. IPHC glossary of terms and abbreviations. IPHC, Seattle, Washington, USA. [online] URL: https://www.iphc.int/ the-commission/glossary-of-terms-and-abbreviations

International Pacific Halibut Commission (IPHC). [date unknown]d. IPHC Secretariat. IPHC, Seattle, Washington, USA. [online] URL: https://www.iphc.int/locations/map

International Pacific Halibut Commission (IPHC). [date unknown]e. Science and research. IPHC, Seattle, Washington, USA. [online] URL: https://www.iphc.int/management/scienceand-research

International Pacific Halibut Commission (IPHC). [date unknown]f. Environmental regulation of somatic growth. IPHC, Seattle, Washington, USA. [online] URL: https://www.iphc.int/ management/science-and-research/biological-and-ecosystem-scienceresearch-program-bandesrp/bandesrp-growth/environmental-regulationof-somatic-growth

International Pacific Halibut Commission (IPHC). [date unknown]g. Oceanographic monitorization. IPHC, Seattle, Washington, USA. [online] URL: https://www.iphc.int/ management/science-and-research/biological-and-ecosystem-scienceresearch-program-bandesrp/bandesrp-environmental-monitoring/ oceanographic-monitorization

International Pacific Halibut Commission (IPHC). [date unknown] $h$. Management strategy evaluation. IPHC, Seattle, Washington, USA. [online] URL: https://www.iphc.int/ management/science-and-research/management-strategy-evaluation

International Pacific Halibut Commission (IPHC). 2016a. Report of the 18th Session of the IPHC Research Advisory Board. 16 November, Seattle, USA. IPHC, Seattle, Washington, USA.

International Pacific Halibut Commission (IPHC). 2016b. Report of the 92nd Session of the IPHC Interim Meeting. 29-30 November, Seattle, USA. IPHC-2016-IM092-R. IPHC, Seattle, Washington, USA.

International Pacific Halibut Commission (IPHC). $2017 a$. Annual report 2017. IPHC, Seattle, Washington, USA.

International Pacific Halibut Commission (IPHC). $2017 b$. PICES and IPHC: continuing connections. Report for the 2017 IPHC Annual Meeting, 23-27 January, Victoria, Canada. IPHC-2017-AM093-INF04. IPHC, Seattle, Washington, USA.

International Pacific Halibut Commission (IPHC). $2018 a$. Annual report 2018. IPHC, Seattle, Washington, USA.
International Pacific Halibut Commission (IPHC). 2018b. Report of the 94th Session of the IPHC Annual Meeting. 22-26 January, Portland, USA. IPHC-2018-AM094-R. IPHC, Seattle, Washington, USA.

International Pacific Halibut Commission (IPHC). 2019a. Pacific Halibut Fishery Regulations. IPHC, Seattle, Washington, USA.

International Pacific Halibut Commission (IPHC). 2019b. Report of the 13th Session of the IPHC Management Strategy Advisory Board. 6-9 May, Sitka, USA. IPHC-2019-MSAB013-R. IPHC, Seattle, Washington, USA.

International Pacific Halibut Commission (IPHC). 2019c. Report of the 95th Session of the IPHC Annual Meeting. 28 January-1 February, Victoria, Canada. IPHC-2019-AM095-R. IPHC, Seattle, Washington, USA.

International Pacific Halibut Commission (IPHC). $2020 a$. Annual report 2019. IPHC, Seattle, Washington, USA.

International Pacific Halibut Commission (IPHC). 2020b. Report of the 96th Session of the IPHC Annual Meeting. 3-7 February, Anchorage, USA. IPHC-2020-AM096-R. IPHC, Seattle, Washington, USA.

International Scientific Committee for Tuna and Tuna-like Species in the North Pacific Ocean (ISC). [date unknown]. Membership. [online] URL: http://isc.fra.go.jp/organization/ membership.html

International Scientific Committee for Tuna and Tuna-like Species in the North Pacific Ocean (ISC). 2014a. Report of the Fourteenth Meeting of the International Scientific Committee for Tuna and Tuna-like Species in the North Pacific Ocean, Plenary Session. 16-21 July, Taipei, Taiwan.

International Scientific Committee for Tuna and Tuna-like Species in the North Pacific Ocean (ISC). 2014b. Seminar report: impacts of climate change on tuna and tuna-like species. Annex 15 to the Report of the Fourteenth Meeting of the International Scientific Committee for Tuna and Tuna-like Species in the North Pacific Ocean, Plenary Session. 16-21 July, Taipei, Taiwan.

International Scientific Committee for Tuna and Tuna-like Species in the North Pacific Ocean (ISC). 2016. Report of the Sixteenth Meeting of the International Scientific Committee for Tuna and Tuna-like Species in the North Pacific Ocean, Plenary Session. 13-18 July, Sapporo, Japan.

International Scientific Committee for Tuna and Tuna-like Species in the North Pacific Ocean (ISC). 2017. Report of the Seventeenth Meeting of the International Scientific Committee for Tuna and Tuna-like Species in the North Pacific Ocean, Plenary Session. 12-17 July, Vancouver, Canada.

International Scientific Committee for Tuna and Tuna-like Species in the North Pacific Ocean (ISC). 2018. Report of the Eighteenth Meeting of the International Scientific Committee for Tuna and Tuna-like Species in the North Pacific Ocean, Plenary Session. 11-16 July, Yeosu, Korea.

International Scientific Committee for Tuna and Tuna-like Species in the North Pacific Ocean (ISC). 2019. Report of the Nineteenth Meeting of the International Scientific Committee for 
Tuna and Tuna-like Species in the North Pacific Ocean, Plenary Session. 11-15 July, Taipei, Taiwan.

Jansen, T., E. E. Nielsen, N. Rodríguez-Ezpeleta, H. Arrizabalaga, S. Post, and B. R. MacKenzie. 2020. Atlantic bluefin tuna (Thunnus thynnus) in Greenland-mixed-stock origin, diet, hydrographic conditions and repeated catches in this new fringe area. Canadian Journal of Fisheries and Aquatic Sciences. https://doi.org/10.1139/cjfas-2020-0156

Jansen, T., S. L. Post, T. Kristiansen, G. J. Óskarsson, J. Boje, B. R. MacKenzie, M. Broberg, and H. Siegstad. 2016. Ocean warming expands habitat of a rich natural resource and benefits a national economy. Ecological Applications 26(7):2021-2032. https://doi.org/10.1002/eap.1384

Juan-Jordá, M. J., H. Murua, H. Arrizabalaga, N. K. Dulvy, and V. Restrepo. 2018a. Report card on ecosystem-based fisheries management in tuna regional fisheries management organizations. Fish and Fisheries 19:321-339. https://doi.org/10.1111/faf.12256

Juan-Jordá, M. J, R. Zarradand, and A. Hanke. 2018b. A proposal of ecosystem indicators to monitor the trophic relationships component for the ICCAT ecosystem report card. SCRS/2018/073. International Commission for the Conservation of Atlantic Tunas, Madrid, Spain.

Keith, S., T. Kong, L. Sadorus, I. Stewart and G. Williams, editors. 2014. The Pacific halibut: biology, fishery, and management. IPHC Technical Report No. 59. International Pacific Halibut Commission, Seattle, Washington, USA.

Kell, L. T., and B. E. Luckhurst. 2018. Extending the indicatorbased ecosystem report card to the whole ecosystem: a preliminary example based on the Sargasso Sea. SCRS/2018/067. International Commission for the Conservation of Atlantic Tunas, Madrid, Spain.

Koen-Alonso, M., P. Pepin, M. J. Fogarty, A. Kenny, and E. Kenchington. 2019. The Northwest Atlantic Fisheries Organization roadmap for the development and implementation of an ecosystem approach to fisheries: structure, state of development, and challenges. Marine Policy 100:342-352. https:// doi.org/10.1016/j.marpol.2018.11.025

Laffoley, D., and J. M. Baxter, editors. 2016. Explaining ocean warming: causes, scale, effects and consequences. International Union for Conservation of Nature, Gland, Switzerland. https:// doi.org/10.2305/IUCN.CH.2016.08.en

Lehodey, P., I. Senina, O. Titaud, B. Calmettes, A. Conchon, A. Dragon, S. Nicol, S. Caillot, J. Hampton, and P. Williams. 2014. Project 62: SEAPODYM applications in WCPO. WCPFCSC10-2014/EB-WP-02. Western and Central Pacific Fisheries Commission, Kolonia, Micronesia.

MacKenzie, B. R., M. R. Payne, J. Boje, J. L. Høyer, and H. Siegstad. 2014. A cascade of warming impacts brings bluefin tuna to Greenland waters. Global Change Biology 20:2484-2491. https://doi.org/10.1111/gcb.12597

McCaughran, D. A., and S. H. Hoag. 1992. The 1979 Protocol to the Convention and Related Legislation. IPHC Technical Report No. 26. International Pacific Halibut Commission, Seattle, Washington, USA.
McCreary, S., and B. Brooks. 2012. Performance review of the International Pacific Halibut Commission. International Pacific Halibut Commission, Seattle, Washington, USA.

McDorman, T. L. 1998. A Canadian view of the 1999 CanadaUnited States Pacific Salmon Agreement: a positive turning point? Willamette Journal of International Law and Dispute Resolution 6(1):99-112.

McKinnell, S. 2017. Atmospheric and oceanic extrema in 2015 and 2016 and their effect on North American Salmon. PSC Technical Report No. 37. Pacific Salmon Commission, Vancouver, British Columbia, Canada.

McRae, D. 2001. The negotiation of the 1999 Pacific Salmon Agreement. Canada-United States Law Journal 27:267-284.

Molenaar, E. J. 2019. Participation in regional fisheries management organizations. Pages 103-130 in R. Caddell and E. J. Molenaar, editors. Strengthening international fisheries law in an era of changing oceans. Hart, Oxford, UK. https://doi. org/10.5040/9781509923373.ch-006

Moon, D.-Y. 2016. Progress in the management of North Pacific bottom fisheries in conjunction with establishment of the NPFC. North Pacific Fisheries Commission, Tokyo, Japan. [online] URL: http://www.un.org/depts/los/reference files/Presentations/ PPT/Segment4/DYM.pdf

Muhling, B. S., Y. Liu, S. K. Lee, J. T. Lamkin, E. Malea, J. Llopiz, G. W. Ingram Jr., J. M. Quattro, J. F. Walter, K. Doering, M. K. Roffer, and F. Muller-Karger. 2014. Past, ongoing and future research on climate change impacts on tuna and billfishes in the Western Atlantic. SCRS/2014/174. International Commission for the Conservation of Atlantic Tunas, Madrid, Spain.

Munro, G., P. Tyedmers, R. McKelvey, K. Miller, and T. L. McDorman. 2001. The 1999 Pacific Salmon Agreement: a sustainable solution? Canadian-American Public Policy 47:1-60.

National Marine Fisheries Service. 2019. 1st Quarter 2019 update. National Oceanic and Atmospheric Administration, Silver Spring, Maryland, USA.

National Oceanic and Atmospheric Administration (NOAA) Fisheries. 2017. 2017 Report to Congress on the Status of U.S. Fisheries. NOAA, Silver Spring, Maryland, USA.

Northwest Atlantic Fisheries Organization (NAFO). [date unknown]a. Species. NAFO, Halifax, Nova Scotia, Canada. [online] URL: http://www.nafo.int/Science/Species

Northwest Atlantic Fisheries Organization (NAFO). [date unknown] b. Ecosystem approach. NAFO, Halifax, Nova Scotia, Canada. [online] URL: http://www.nafo.int/Science/Frameworks/ Ecosystem-Approach

Northwest Atlantic Fisheries Organization (NAFO). 2001a. Report of the NAFO/NEAFC Working Group on Oceanic Redfish. 13-14 February, Reykjavik, Iceland. NAFO/FC Doc. 01.3. NAFO, Halifax, Nova Scotia, Canada.

Northwest Atlantic Fisheries Organization (NAFO). $2001 b$. Report of the special fisheries commission meeting. 28-30 March, Copenhagen, Denmark. NAFO/FC Doc. 01/7. NAFO, Halifax, Nova Scotia, Canada. 
Northwest Atlantic Fisheries Organization (NAFO) 2004. NAFO precautionary approach framework. NAFO/FC Doc. 04/18. NAFO, Halifax, Nova Scotia, Canada.

Northwest Atlantic Fisheries Organization (NAFO). 2010. Scientific Council meeting report. 3-16 June. NAFO, Halifax, Nova Scotia, Canada.

Northwest Atlantic Fisheries Organization (NAFO). 2011. Northwest Atlantic Fisheries Organization conservation and enforcement measures. NAFO/FC Doc. 11/1. NAFO, Halifax, Nova Scotia, Canada.

Northwest Atlantic Fisheries Organization (NAFO). 2015. Report of the 8th meeting of the NAFO Scientific Council (SC) Working Group on Ecosystem Science and Assessment (WGESA). 17-26 November, Dartmouth, Canada. NAFO SCS Doc. 15/19. NAFO, Halifax, Nova Scotia, Canada.

Northwest Atlantic Fisheries Organization (NAFO). $2016 a$. Report of the Scientific Council meeting. 3-16 June, Halifax, Canada. NAFO SCS Doc. 16-14 Rev. NAFO, Halifax, Nova Scotia, Canada.

Northwest Atlantic Fisheries Organization (NAFO). $2016 b$. Report of the Fisheries Commission and its subsidiary body (STACTIC), 38th annual meeting of NAFO. 19-23 September, Varadero, Cuba. NAFO/FC Doc. 16-20. NAFO, Halifax, Nova Scotia, Canada.

Northwest Atlantic Fisheries Organization (NAFO). $2017 a$. Convention on Cooperation in the Northwest Atlantic Fisheries. NAFO, Halifax, Nova Scotia, Canada.

Northwest Atlantic Fisheries Organization (NAFO). $2017 b$. Report of the NAFO Joint Commission-Scientific Council Working Group on Ecosystem Approach Framework to Fisheries Management (WG-EAFFM) Meeting. 14 July, Dartmouth, Canada. NAFO/COM Doc. 17-07. NAFO, Halifax, Nova Scotia, Canada.

Northwest Atlantic Fisheries Organization (NAFO). 2017c. Report of the Commission and its subsidiary bodies (STACTIC and STACFAD), 39th annual meeting of NAFO. 18-22 September, Montreal, Canada. NAFO/COM Doc. 17-29 (Revised). NAFO, Halifax, Nova Scotia, Canada.

Northwest Atlantic Fisheries Organization (NAFO). $2018 a$. Report of the Scientific Council meeting. 1-14 June, Halifax, Canada. NAFO SCS Doc. 18-19. NAFO, Halifax, Nova Scotia, Canada.

Northwest Atlantic Fisheries Organization (NAFO). $2018 b$. Report of the NAFO Commission and its subsidiary bodies (STACTIC and STACFAD), 40th annualmeeting of NAFO. 17-21 September, Tallinn, Estonia. NAFO/COM Doc. 18-28. NAFO, Halifax, Nova Scotia, Canada.

Northwest Atlantic Fisheries Organization (NAFO). $2018 c$. NAFO performance review panel report 2018. NAFO, Halifax, Nova Scotia, Canada.

Northwest Atlantic Fisheries Organization (NAFO). 2019a. Conservation and enforcement measures 2019. NAFO, Halifax, Nova Scotia, Canada.
Northwest Atlantic Fisheries Organization (NAFO). $2019 b$. Report of the NAFO Joint Commission-Scientific Council Working Group on Ecosystem Approach Framework to Fisheries Management (WG-EAFFM) meeting. 16-18 July, Dartmouth, Canada. NAFO/COM-SC Doc. 19-03. NAFO, Halifax, Nova Scotia, Canada.

Northwest Atlantic Fisheries Organization (NAFO). 2019c. Report of the 12th Meeting of the NAFO Scientific Council Working Group on Ecosystem Science and Assessment (WGESA). 19-28 November, Dartmouth, Canada. NAFO SCS Doc. 19/25. NAFO, Halifax, Nova Scotia, Canada.

Northwest Atlantic Fisheries Organization (NAFO). 2019d. Report of the NAFO Commission and its subsidiary bodies (STACTIC and STACFAD), 41 st annual meeting of NAFO. 23-27 September, Bordeaux, France. NAFO/COM Doc. 19-34. NAFO, Halifax, Nova Scotia, Canada.

North Atlantic Salmon Conservation Organization (NASCO). [date unknown] a. About NASCO. NASCO, Edinburgh, UK. [online] URL: http://www.nasco.int/about.html

North Atlantic Salmon Conservation Organization (NASCO). [date unknown]b. West Greenland salmon fishery measures. NASCO, Edinburgh, UK. [online] URL: https://nasco.int/ regulation/west-greenland-salmon-fisheries/

North Atlantic Salmon Conservation Organization (NASCO). [date unknown]c. Faroese salmon fishery measures. NASCO, Edinburgh, UK. [online] URL: https://nasco.int/regulation/ faroese-salmon-fishery-measures/

North Atlantic Salmon Conservation Organization (NASCO). [date unknown]d. International Atlantic Salmon Research Board. NASCO, Edinburgh, UK. [online] URL: https://salmonatsea. $\mathrm{com} /$

North Atlantic Salmon Conservation Organization (NASCO). [date unknown]e. Salmon and people in a changing world. NASCO, Edinburgh, UK. [online] URL: http://www.nasco.int/iys.html

North Atlantic Salmon Conservation Organization (NASCO). 1998. Agreement on adoption of a precautionary approach. Council Doc. CNL (98) 46. NASCO, Edinburgh, UK.

North Atlantic Salmon Conservation Organization (NASCO). 1999. Action plan for application of the precautionary approach. Council Doc. CNL (99) 48. NASCO, Edinburgh, UK.

North Atlantic Salmon Conservation Organization (NASCO). 2001. NASCO plan of action for the application of the precautionary approach to the protection and restoration of Atlantic salmon habitat. Council Doc. CNL (01) 51. NASCO, Edinburgh, UK.

North Atlantic Salmon Conservation Organization (NASCO). 2010. NASCO guidelines for the protection, restoration and enhancement of Atlantic salmon habitat. Council Doc. CNL (10) 51. NASCO, Edinburgh, UK.

North Atlantic Salmon Conservation Organization (NASCO). 2011. Report of the ICES Advisory Committee. Council Doc. CNL (11) 8. NASCO, Edinburgh, UK. 
North Atlantic Salmon Conservation Organization (NASCO). 2012. NASCO external performance review. Council Doc. CNL (12) 11. NASCO, Edinburgh, UK.

North Atlantic Salmon Conservation Organization (NASCO). 2013. Convention for the Conservation of Salmon in the North Atlantic Ocean. Pages 7-19 in Handbook of basic texts. NASCO, Edinburgh, UK. [online] URL: http://salmonatsea.com/wpcontent/uploads/2020/09/NASCO Handbook.pdf

North Atlantic Salmon Conservation Organization (NASCO). 2014a. Management of single and mixed stock fisheries, with particular focus on fisheries on stocks below their conservation limit. Report of a theme-based special session of the council of NASCO. 4 June, Saint-Malo, France. Council Doc. CNL (14) 68. NASCO, Edinburgh, UK.

North Atlantic Salmon Conservation Organization (NASCO). 2014b. The management approach to the West Greenland salmon fishery-fairness and balance in the management of distant-water fisheries. Council Doc. CNL (14) 44. NASCO, Edinburgh, UK.

North Atlantic Salmon Conservation Organization (NASCO). 2016a. Report for scientific advice from ICES. Council Doc. CNL (16) 12. NASCO, Edinburgh, UK.

North Atlantic Salmon Conservation Organization (NASCO). 2016b. SALSEA-Track: innovative research to solve the mystery of Atlantic salmon mortality at sea. NASCO, Edinburgh, UK.

North Atlantic Salmon Conservation Organization (NASCO). 2018. Management and sampling of the St. Pierre and Miquelon salmon fishery. Council Doc. CNL (18) 17. NASCO, Edinburgh, UK.

North Atlantic Salmon Conservation Organization (NASCO). 2019a. Report from the Tromso symposium on the recommendations to address future management challenges. Council Doc. CNL (19)16. NASCO, Edinburgh, UK.

North Atlantic Salmon Conservation Organization (NASCO). 2019b. Summary of annual program reports under the 2017-2018 implementation plans. Council Doc. CNL (19) 13. NASCO, Edinburgh, UK.

North Atlantic Salmon Conservation Organization (NASCO). 2019c. Report of the meeting of the Implementation Plan / Annual Progress Report Review Group for the review of annual progress reports under the second cycle of reporting (2013-2018). Council Doc. CNL (19) 12. NASCO, Edinburgh, UK.

North-East Atlantic Fisheries Commission (NEAFC). 2004. Recommendation I for the 22nd annual meeting on management measures on pelagic fishery for redfish. NEAFC, London, UK.

North-East Atlantic Fisheries Commission (NEAFC). 2010. Recommendation II - 2010 from the 28th annual meeting on conservation and management measures for deep and shallow pelagic redfish in the Irminger Sea and adjacent waters in 2010. NEAFC, London, UK.

North-East Atlantic Fisheries Commission (NEAFC). 2011. Report of the 30th annual meeting of the North-East Atlantic Fisheries Commission. 7-11 November, NEAFC Headquarters, London, Vol. I. NEAFC, London, UK.
North-East Atlantic Fisheries Commission (NEAFC). 2019. Recommendation 1. Recommendation on communication and management measures for deep and shallow pelagic redfish in the Irminger Sea and adjacent waters in the NEAFC convention area for 2019. NEAFC, London, UK.

North Pacific Anadromous Fisheries Commission (NPAFC). 2019. 2019 Workshop presentations. NPAFC, Vancouver, British Columbia, Canada. [online] URL: https://npafc.org/workshoppresentations-2019/

North Pacific Fisheries Commission (NPFC). [date unknown] . About NPFC: NPFC area of application. NPFC, Tokyo, Japan. [online] URL: https://www.npfc.int/about npfc/convention and_npfc_area_of_application

North Pacific Fisheries Commission (NPFC). [date unknown]b. Status of the NPFC convention. NPFC, Tokyo, Japan. [online] URL: $\underline{\text { https://www.npfc.int/status-npfc-convention }}$

North Pacific Fisheries Commission (NPFC). [date unknown]c. Scientific Committee 2017-2021 research plan. NPFC, Tokyo, Japan. [online] URL: https://www.npfc.int/2017-2021-researchplan

North Pacific Fisheries Commission (NPFC). [date unknown]d. Fisheries overview. NPFC, Tokyo, Japan. [online] URL: https:// www.npfc.int/fisheries-overview

North Pacific Fisheries Commission (NPFC). 2014. Report of the International Symposium for Pacific saury. NPFC, Tokyo, Japan. [online] URL: https://www.npfc.int/sites/default/files/2017-02/ International $\% 20$ Symposium $\% 20$ for $\% 20$ Pacific $\% 20$ Saury $\% 20$ Report. pdf

North Pacific Fisheries Commission (NPFC). 2017a. Third Commission meeting report. 13-15 July, Sapporo, Japan. NPFC-2017-COM03-Final Report. NPFC, Tokyo, Japan.

North Pacific Fisheries Commission (NPFC). $2017 b$. Conservation and management measure for bottom fisheries and protection of vulnerable marine ecosystems in the Northeastern Pacific Ocean. CMM 2017-06. NPFC, Tokyo, Japan.

North Pacific Fisheries Commission (NPFC). 2018a. Fourth Commission meeting report. 3-5 July, Tokyo, Japan. NPFC-2018COM04-Final Report. NPFC, Tokyo, Japan.

North Pacific Fisheries Commission (NPFC). $2018 b$. Conservation and management measure for bottom fisheries and protection of vulnerable marine ecosystems in the Northwestern Pacific Ocean. CMM 2018-05. NPFC, Tokyo, Japan.

North Pacific Fisheries Commission (NPFC). 2019. Fifth Commission meeting report. 16-18 July, Tokyo, Japan. NPFC-2019-COM05-Final Report. NPFC, Tokyo, Japan.

Pacific Salmon Commission (PSC). [date unknown]a. Chinook Technical Committee. PSC, Vancouver, British Columbia, Canada. [online] URL: https://www.psc.org/about-us/structure/ committees/technical/chinook/

Pacific Salmon Commission (PSC). [date unknown]b. Standing committees: Standing Committee on Scientific Cooperation. PSC, Vancouver, British Columbia, Canada. [online] URL: http:// www.psc.org/about-us/structure/committees/standing/ 
Pacific Salmon Commission (PSC). 2017. Elaboration of a strategy for consideration of annual variation in environmental indicators and salmon production and its implications for fisheries management under the Pacific Salmon Treaty. PSC Fall Meeting Summary, 23-26 October, Suquamish, USA. PSC, Vancouver, British Columbia, Canada.

Pacific Salmon Commission (PSC). 2018. CSC 02/15/2018 Report to Commission on 2017/2018 Work Plan, 33rd annual meeting. 12-16 February, Vancouver, Canada. PSC, Vancouver, British Columbia, Canada.

Pacific Salmon Commission (PSC). 2019. Committee on Scientific Cooperation (CSC) annual report to the Commission, 34th annual meeting. 11-15 February, Portland, USA. PSC, Vancouver, British Columbia, Canada.

Palacios-Abrantes, J., U. R. Sumaila, and W. W. L. Cheung. 2020. Challenges to transboundary fisheries management in North America under climate change. Ecology and Society 25(4):41. https://doi.org/10.5751/ES-11743-250441

Pentz, B., and N. Klenk. 2017. The 'responsiveness gap' in RFMOs: the critical role of decision-making policies in the fisheries management response to climate change. Ocean \& Coastal Management 145:44-51. https://doi.org/10.1016/j. ocecoaman.2017.05.007

Pentz, B., N. Klenk, S. Ogle, and J. A. D. Fisher. 2018. Can regional fisheries management organizations (RFMOs) manage resources effectively during climate change? Marine Policy 92:13-20. https://doi.org/10.1016/j.marpol.2018.01.011

Pershing, A. J., M. A. Alexander, C. M. Hernandez, L. A. Kerr, A. Le Bris, K. E. Mills, J. A. Nye, N. R. Record, H. A. Scannel, J. D. Scott, G. D. Sherwood, and A. C. Thomas. 2015. Slow adaptation in the face of rapid warming leads to collapse of the Gulf of Maine cod fishery. Science 350(6262):809-812. https:// doi.org/10.1126/science.aac9819

PICES (North Pacific Marine Science Organization). [date unknown]. FUTURE scientific program: forecasting and understanding trends, uncertainty and responses of North Pacific marine ecosystems. PICES, Sidney, British Columbia, Canada. [online] URL: https://meetings.pices.int/Members/ScientificPrograms/FUTURE

Pinsky, M. L., G. Raygondeau, R. Cuddell, J. Palacids-Abrantes, J. Spijkers, and W. W. L. Cheung. 2018. Preparing ocean governance for species on the move. Science 360(6394)1189-1191. https://doi.org/10.1126/science.aat2360

Planas, J. P. 2016. IPHC 5-year research program, 92nd session of the IPHC interim meeting. 29-30 November, Seattle, USA. IPHC, Seattle, Washington, USA.

Plate, E., R. C. Bocking, and K. K. English. 2009. Responsible fishing in Canada's Pacific region salmon fisheries. Pacific Fisheries Resource Conservation Council, Vancouver, British Columbia, Canada.

Polovina, J. J., E. A. Howell, and M. Abecassis. 2008. Ocean's least productive waters are expanding. Geophysical Research Letters 35:L03618. https://doi.org/10.1029/2007GL031745
Pons, M., M. C. Melnychuk, and R. Hilborn. 2018. Management effectiveness of large pelagic fisheries in the high seas. Fish and Fisheries 19:260-270. https://doi.org/10.1111/faf.12253

Pudden, E. J., and D. L. VanderZwaag. 2010. Canada-United States bilateral fisheries management in the Gulf of Maine: struggling towards sustainability under the radar screen. Pages 175-207 in D. A. Russell and D. L. VanderZwaag, editors. Recasting transboundary fisheries management arrangements in light of sustainability principles: Canadian and international perspectives. Martinus Nijhoff, Leiden, The Netherlands. https:// doi.org/10.1163/ej.9789004174405.i-545.46

Rayfuse, R. 2019. Addressing climate change impacts in regional fisheries management organizations. Pages 247-268 in R. Caddell and E. J. Molenaar, editors. Strengthening international fisheries law in an era of changing oceans. Hart, Oxford, UK. https://doi. org/10.5040/9781509923373.ch-011

Rogers, A. D. 2015. Environmental change in the deep ocean. Annual Review of Environment and Resources 40:1-38. https://doi. org/10.1146/annurev-environ-102014-021415

Russell, D. A. 2010. NAFO and ICCAT: the implementation of sustainability principles and practices in the management of straddling stocks and highly migratory species. Pages 239-305 in D. A. Russell and D. L. VanderZwaag, editors. Recasting transboundary fisheries management arrangements in light of sustainability principles: Canadian and international perspectives. Martinus Nijhoff, Leiden, The Netherlands. https://doi. org/10.1163/ej.9789004174405.i-545.58

Russell, D. A., and D. L. VanderZwaag. 2010a. Ecosystem and precautionary approaches to international fisheries governance: beacons of hope, seas of confusion and illusion. Pages 25-69 in D. A. Russell and D. L. VanderZwaag, editors. Recasting transboundary fisheries management arrangements in light of sustainability principles: Canadian and international perspectives. Martinus Nijhoff, Leiden, The Netherlands. https://doi. org/10.1163/ej.9789004174405.i-545.14

Russell, D. A. and D. L. VanderZwaag. 2010b. Recasting transboundary fisheries management arrangements in light of sustainability principles. Pages 1-6 in D. A. Russell and D. L. VanderZwaag, editors. Recasting transboundary fisheries management arrangements in light of sustainability principles: Canadian and international perspectives. Martinus Nijhoff, Leiden, The Netherlands. https://doi.org/10.1163/ej.9789004174405. i-545.8

Saunders, P., and M. Haward. 2016. Politics, science, and species protection law: a comparative consideration of southern and Atlantic bluefin tuna. Ocean Development \& International Law 47 (4):348-367. https://doi.org/10.1080/00908320.2016.1229940

Secretariat of the Convention on Biological Diversity. 2014. An updated synthesis of the impacts of ocean acidification on marine biodiversity. S. Hennige, J. M. Roberts, and P. Williamson, editors. CBD Technical Series No. 75. Secretariat of the Convention on Biological Diversity, Montreal, Quebec, Canada.

Seggel, A., and C. DeYoung. 2016. Climate change implications for fisheries and aquaculture: summary of the findings of the 
Intergovernmental Panel on Climate Change Fifth Assessment Report. Fisheries and Aquaculture Circular No. 1122. Food and Agriculture Organization, Rome, Italy.

Shum, P., C. Passpoulie, K. Kristinsson, and S. Mariani. 2015. Three-dimensional post-glacial expansion and diversification of an exploited oceanic fish. Molecular Ecology 24:3652-3667. https://doi.org/10.1111/mec.13262

Soomai, S. S. 2017. The science-policy interface in fisheries management: insights about the influence of organizational structure and culture on information pathways. Marine Policy 81:53-63. https://doi.org/10.1016/j.marpol.2017.03.016

Stewart, I., and R. Webster. 2017. Overview of data sources for the Pacific halibut stock assessment, harvest strategy policy, andrelated analyses. IPHC-2018-AM094-09. International Pacific Halibut Commission, Seattle, Washington, USA.

Sumaila, U. R., J. Palacios-Abrantes, and W. W. L. Cheung. 2020. Climate change, shifting threat points, and the management of transboundary fish stocks. Ecology and Society 25(4):40. https:// doi.org/10.5751/ES-11660-250440

Tagami, D., H. Wang, and Y. Chang. 2014. Spatial distribution of swordfish catches for longline fisheries in the Western and Central North Pacific and Eastern Ocean. ISC/14/BILLWG-1/03. International Scientific Committee for Tuna and Tuna-like Species in the North Pacific Ocean.

Thomson, A. 2003. The management of redfish (Sebastes Mentella) in the North Atlantic Ocean - a stock in movement. Pages 192-199 in Papers presented at the Norway-FAO expert consultation on the management of shared stocks. 7-10 October 2002, Bergen, Norway. FAO Fisheries Report No. 695, Supplement. Food and Agriculture Organization, Rome, Italy.

Thorstad, E. B., F. Whoriskey, A. H. Rikardsen, and K. Aarestrup. 2011. Aquatic nomads: the life and migrations of the Atlantic salmon. Pages 1-32 in Ø. Aas, S. Einum, A. Klemetsen, and J. Skurdal, editors. Atlantic salmon ecology. First edition. Wiley-Blackwell, Chinchester, UK. https://doi.org/10.1002/9781444327755. $\underline{\mathrm{ch} 1}$

Transboundary Management Guidance Committee (TMGC). 2014. Transboundary Management Guidance Committee Guidance Document 2014/01. Fisheries and Oceans Canada, Ottawa, Ontario, Canada, and National Oceanic and Atmospheric Administration Fisheries, Silver Spring, Maryland, USA.

Transboundary Management Guidance Committee (TMGC). 2018. Transboundary Management Guidance Committee Guidance Document 2018/01. Fisheries and Oceans Canada, Ottawa, Ontario, Canada, and National Oceanic and Atmospheric Administration Fisheries, Silver Spring, Maryland, USA.

Transboundary Management Guidance Committee (TMGC). 2019. Transboundary Management Guidance Committee Guidance Document 2019/01. Fisheries and Oceans Canada, Ottawa, Ontario, Canada, and National Oceanic and Atmospheric Administration Fisheries, Silver Spring, Maryland, USA.

Transboundary Resource Assessment Committee (TRAC). 2018a. Georges Bank yellowtail flounder status report 2018/03. Fisheries and Oceans Canada, Ottawa, Ontario, Canada, and
National Oceanic and Atmospheric Administration Fisheries, Silver Spring, Maryland, USA.

Transboundary Resource Assessment Committee (TRAC). 2018b. Eastern Georges Bank haddock status update 2018/02. Fisheries and Oceans Canada, Ottawa, Ontario, Canada, and National Oceanic and Atmospheric Administration Fisheries, Silver Spring, Maryland, USA.

Transboundary Resources Steering Committee. 2014. U.S./ Canada Transboundary Resources Steering Committee. Meeting notes, 11 September. Boston, Massachusetts, USA. [online] URL: http://www.bio.gc.ca/info/intercol/sc-cd/documents/sc_minutes_sept2014eng.pdf

Transboundary Resources Steering Committee. 2016. Canada/U. S. Transboundary Resources Steering Committee. Meeting minutes, 8-9 September. Boston, Massachusetts, USA. http:// www.bio.gc.ca/info/intercol/sc-cd/documents/sc_minutes_sept2016 eng. pdf

United Nations General Assembly (UNGA). 2004. Sustainable fisheries, including through the 1995 Agreement for the implementation of the provisions of the United Nations Convention on the Law of the Sea of 10 December 1982 relating to the conservation and management of straddling fish stocks and highly migratory fish stocks, and related instruments. A/RES/59/25. UNGA, New York, New York, USA.

United Nations General Assembly (UNGA). 2005. Sustainable fisheries, including through the 1995 Agreement for the implementation of the provisions of the United Nations Convention on the Law of the Sea of 10 December 1982 relating to the conservation and management of straddling fish stocks and highly migratory fish stocks, and related instruments. A/RES/60/31. UNGA, New York, New York, USA.

United Nations General Assembly (UNGA). 2006. Sustainable fisheries, including through the 1995 Agreement for the Implementation of the Provisions of the United Nations Convention on the Law of the Sea of 10 December 1982 relating to the Conservation and Management of Straddling Fish Stocks and Highly Migratory Fish Stocks, and related instruments. A/ RES/61/105. UNGA, New York, New York, USA.

United States Atlantic Salmon Assessment Committee. 2018. Annual report of the U.S. Atlantic Salmon Assessment Committee. Report No. 37 - 2017 Activities. 26 February-2 March, Portland, USA. National Oceanic and Atmospheric Administration, Silver Spring, Maryland, USA.

van der Marel, E. R. 2019. Problems and progress in combating IUU Fishing. Pages 291-318 in R. Caddell and E. J. Molenaar, editors. Strengthening international fisheries law in an era of changing oceans. Hart, Oxford, UK. https://doi.org/10.5040/9781509923373.ch-013

VanderZwaag, D. L., M. Bailey, and N. L. Shackell. 2017. Canada-U.S. fisheries management in the Gulf of Maine: taking stock and charting future coordinates in the face of climate change. Ocean Yearbook Online 31:1-26. https://doi. org/10.1163/22116001-03101002

VanderZwaag, D. L., M. C. Engler-Palma, and J. A. Hutchings. 2011. Canada's Species at Risk Act and Atlantic salmon: cascade 
of promises, trickles of protection, sea of challenges. Journal of Environmental Law and Practice 22:267-307.

VanderZwaag, D. L., and E. J. Pudden. 2010. The North Atlantic Salmon Conservation Organization (NASCO): surpassing a 25 year voyage in transboundary cooperation but still confronting a sea of challenges. Pages 307-346 in D. A. Russell and D. L. VanderZwaag, editors. Recasting transboundary fisheries management arrangements in light of sustainability principles: Canadian and international perspectives. Martinus Nijhoff, Leiden, The Netherlands. https://doi.org/10.1163/ej.9789004174405. i-545.62

Western and Central Pacific Fisheries Commission (WCPFC). [date unknown]a. Convention text. WCPFC, Kolonia, Micronesia. [online] URL: https://www.wcpfc.int/convention$\underline{\text { text }}$

Western and Central Pacific Fisheries Commission (WCPFC). [date unknown] b. About WCPFC. WCPFC, Kolonia, Micronesia. [online] URL: https://www.wcpfc.int/about-wcpfc

Western and Central Pacific Fisheries Commission (WCPFC). 2003. Northern Committee proposal: views of the United States. Preparatory Conference for the Commission for the Conservation and Management of Highly Migratory Fish Stocks in the Western and Central Pacific. 29 September-3 October, Rarotonga, Cook Islands. WCPFC/PrepCon/DP.18. WCPFC, Kolonia, Micronesia.

Western and Central Pacific Fisheries Commission (WCPFC). 2005a. Memorandum of understanding between WCPFC and ISC. WCPFC, Kolonia, Micronesia. [online] URL: https://www. wcpfc.int/doc/mou-between-wcpfc-and-isc

Western and Central Pacific Fisheries Commission (WCPFC). 2005b. Conservation and management measure for North Pacific albacore. CMM 2005-03. WCPFC, Kolonia, Micronesia.

Western and Central Pacific Fisheries Commission (WCPFC). 2007a. The relationship between the International Scientific Committee, the Northern Committee and the Scientific Committee in respect to the northern stocks. Third Regular Session of the Scientific Committee. 13-24 August, Honolulu, USA. WCPFCSC3/GN IP-2. WCPFC, Kolonia, Micronesia.

Western and Central Pacific Fisheries Commission (WCPFC). 2007b. Fourth regular session. 2-7 December, Tumon, USA. WCPFC, Kolonia, Micronesia.

Western and Central Pacific Fisheries Commission (WCPFC). 2012a. Review of the performance of WCPFC. WCPFC8-2011/2012. WCPFC, Kolonia, Micronesia.

Western and Central Pacific Fisheries Commission (WCPFC). 2012b. Scientific Committee eighth regular session summary report. 7-15 August, Busan, Korea. WCPFC, Kolonia, Micronesia.

Western and Central Pacific Fisheries Commission (WCPFC). 2014. Scientific Committee tenth regular session summary report. 6-14 August, Majuro, Marshall Islands. WCPFC, Kolonia, Micronesia.

Western and Central Pacific Fisheries Commission (WCPFC). 2015. Northern Committee eleventh regular session summary report. 31 August-3 September, Sapporo, Japan. WCPFC, Kolonia, Micronesia.
Western and Central Pacific Fisheries Commission (WCPFC). 2016a. Summary report of the thirteenth regular session of the Commission. Denarau Island, Fiji. WCPFC, Kolonia, Micronesia.

Western and Central Pacific Fisheries Commission (WCPFC). 2016b. Memorandum of understanding between the Commission for the Conservation and Management of Highly Migratory Fish Stocks in the Western and Central Pacific Ocean and the Pacific Community. WCPFC, Kolonia, Micronesia.

Western and Central Pacific Fisheries Commission (WCPFC). 2016c. Northern Committee twelfth regular session. 29 August-2 September, Fukuoka, Japan. WCPFC, Kolonia, Micronesia.

Western and Central Pacific Fisheries Commission (WCPFC). 2017. Fourteenth regular session of the Commission summary report. 3-7 December, Manila, Philippines. WCPFC, Kolonia, Micronesia.

Western and Central Pacific Fisheries Commission (WCPFC). 2018a. Rules of procedure, as amended by WCPFC15. WCPFC, Kolonia, Micronesia.

Western and Central Pacific Fisheries Commission (WCPFC). 2018b. Conservation and management measure for Pacific bluefin tuna. CMM 2018-02. WCPFC, Kolonia, Micronesia.

Western and Central Pacific Fisheries Commission (WCPFC). 2018c. Northern Committee fourteenth regular session summary report (Revision 1). 3-7 September, Fukuoka, Japan. WCPFC, Kolonia, Micronesia.

Western and Central Pacific Fisheries Commission (WCPFC). 2018d. Fifteenth regular session of the Commission summary report. 10-14 December, Honolulu, USA. WCPFC, Kolonia, Micronesia.

Western and Central Pacific Fisheries Commission (WCPFC). 2019a. Sixteenth regular session of the Commission summary report. 5-11 December, Port Moresby, Papua New Guinea. WCPFC, Kolonia, Micronesia.

Western and Central Pacific Fisheries Commission (WCPFC). 2019b. Northern Committee fifteenth regular session summary report. 3-6 September, Portland, USA. WCPFC, Kolonia, Micronesia.

Western and Central Pacific Fisheries Commission (WCPFC). 2019c. Resolution on climate change as it relates to the Western and Central Pacific Fisheries Commission. Resolution 2019-01. WCPFC, Kolonia, Micronesia.

West Greenland Commission. 2015. Multi-annual regulatory measure for fishing for salmon at West Greenland for 2015, 2016 and 2017. WGC (15) 21. North Atlantic Salmon Conservation Organization, Edinburgh, UK.

West Greenland Commission. 2018a. Multi-annual regulatory measure for fishing for Atlantic salmon at West Greenland. WGC (18) 11. North Atlantic Salmon Conservation Organization, Edinburgh, UK.

West Greenland Commission. 2018b. Report of the thirty-fifth annual meeting of the West Greenland Commission of the North Atlantic Salmon Conservation Organization. 12-15 June, Portland, 
Maine, USA. WGC (18) 12. North Atlantic Salmon Conservation Organization, Edinburgh, UK.

West Greenland Commission. 2019. Report to the West Greenland Commission on the evaluation of the salmon fishery in Greenland in 2018 and measures for the 2019 salmon fishery. WGC (19) 05. North Atlantic Salmon Conservation Organization, Edinburgh, UK.

Wold, C., E. Kondo, and E. Hamilton. 2015. Bringing southern bluefin tuna back from the brink: enhancing understanding of the scientific process in the Western and Central Pacific Fisheries Commission. Boston College Environmental Affairs Law Review 42(2):347-404. 